\title{
X-ray Total Scattering Study of Phases Formed from Cement Phases Carbonation
}

\author{
Ana Cuesta *(D), Angeles G. De la Torre (D) and Miguel A. G. Aranda (D) \\ Departamento de Química Inorgánica, Cristalografía y Mineralogía, Universidad de Málaga, \\ 29071 Málaga, Spain; mgd@uma.es (A.G.D.l.T.); g_aranda@uma.es (M.A.G.A.) \\ * Correspondence: a_cuesta@uma.es
}

check for updates

Citation: Cuesta, A.; De la Torre, A.G.; Aranda, M.A.G. X-ray Total Scattering Study of Phases Formed from Cement Phases Carbonation. Minerals 2021, 11,519. https:// doi.org/10.3390/min11050519

Academic Editors: Krassimir Garbev, Herbert Pöllmann and Jiaqi Li

Received: 13 April 2021

Accepted: 12 May 2021

Published: 14 May 2021

Publisher's Note: MDPI stays neutral with regard to jurisdictional claims in published maps and institutional affiliations.

Copyright: (c) 2021 by the authors. Licensee MDPI, Basel, Switzerland. This article is an open access article distributed under the terms and conditions of the Creative Commons Attribution (CC BY) license (https:// creativecommons.org/licenses/by/ $4.0 /)$.

\begin{abstract}
Carbonation in cement binders has to be thoroughly understood because it affects phase assemblage, binder microstructure and durability performance of concretes. This is still not the case as the reaction products can be crystalline, nanocrystalline and amorphous. The characterisation of the last two types of components are quite challenging. Here, carbonation reactions have been studied in alite-, belite- and ye'elimite-containing pastes, in controlled conditions $\left(3 \% \mathrm{CO}_{2}\right.$ and $\left.\mathrm{RH}=65 \%\right)$. Pair distribution function (PDF) jointly with Rietveld and thermal analyses have been applied to prove that ettringite decomposed to yield crystalline aragonite, bassanite and nano-gibbsite without any formation of amorphous calcium carbonate. The particle size of gibbsite under these conditions was found to be larger $(\sim 5 \mathrm{~nm})$ than that coming from the direct hydration of ye'elimite with anhydrite $(\sim 3 \mathrm{~nm})$. Moreover, the carbonation of mixtures of C-S-H gel and portlandite, from alite and belite hydration, led to the formation of the three crystalline $\mathrm{CaCO}_{3}$ polymorphs (calcite, aragonite and vaterite), amorphous silica gel and amorphous calcium carbonate. In addition to their PDF profiles, the thermal analyses traces are thoroughly analysed and discussed.
\end{abstract}

Keywords: building materials; amorphous phases; nanocrystalline phases; carbonation; Rietveld quantitative phase analysis; pair distribution function; thermal analysis

\section{Introduction}

Concrete, made from Portland cement, water, aggregates, mineral additives and admixtures, is the second largest commodity (in terms of total volume) consumed by mankind after water [1]. The yearly concrete world production is estimated to be 5 tons/person or $\sim 7 \mathrm{~km}^{3}$ ( 18 Gt) [2] and the estimated world concrete stock is $315 \mathrm{Gt}$ [3] which currently results in $\sim 4 \mathrm{Gt} / \mathrm{yr}$ of concrete demolition waste (CDW) [4,5]. Therefore, any chemical reaction in concretes is of huge societal interest because durability of current and future buildings and infrastructures is key to maintaining our well-being.

Carbon dioxide from our atmosphere may react with hydrated/hydrating cement phases in presence of moisture. The carbonation reactions can have a profound impact on: (i) phase assemblage, (ii) binder microstructure and (iii) the durability performances of (reinforced) concretes. A great research effort in carbonation of building materials has been done and this investigation focusses on the phase changes and not on the impact of carbonation on building materials performance properties. The interested reader is addressed to current reviews for overviews of the different processes and their consequences in pastes, mortars and concretes [6-8]. In this work, the research is focussed on the phase changes under carbonation and hence, microstructure and durability modifications are not further considered, although it is acknowledged that these transformations are equally important. Furthermore, carbonation-provoked changes can be considered passive or active. On the one hand, passive carbonation processes cause unwanted and unplanned changes in the outer layer of a concrete exposed to the environment and it is commonly considered as a deterioration (or ageing) mechanism. On the other hand, an active carbonation process results from an intentionally designed procedure to take advantage of the ability 
of calcium-containing cement phases to react with $\mathrm{CO}_{2}$ resulting in a variety of benefits including improved early age mechanical, chemical or environmental performances. Here, just passive changes are considered.

Table 1 summarises the carbonation reactions of the main components in hydrated cement binders which are further investigated here. The current knowledge, related to the phases involved in these reactions, is briefly summarised next. I. Portlandite, crystalline calcium hydroxide, carbonates according to reaction (1) to yield calcium carbonate(s). The crystalline structure(s) of the $\mathrm{CaCO}_{3}$ form will mainly depend upon the dominant conditions during precipitation which could be kinetic or thermodynamic [7]. $\mathrm{CaCO}_{3}$ will precipitate as aragonite, vaterite or even partly containing amorphous calcium carbonate (ACC) under kinetically controlled conditions. Conversely, under a thermodynamically controlled environment, calcite will mainly crystallize. II. Carbonation of C-S-H gel, see reaction (2), proceeds by the removal of calcium ions yielding, initially through a de-calcified gel plus partial carbonation, and finally the formation of amorphous (calcium-containing) silica gel and several forms of $\mathrm{CaCO}_{3}$ [9-14]. The extent of the C-S-H carbonation and the type of product formed depend upon the initial binder $(\mathrm{Ca} / \mathrm{Si}$ ratio of the gel, water content, overall phase assemblage, etc.) as well as the environmental conditions (mainly: time of exposure, $\mathrm{CO}_{2}$ concentration and the relative humidity $(\mathrm{RH})$ ). All calcium carbonate polymorphs and even ACC have been reported as a result of reaction (2). It has been also published that aragonite and vaterite formation seem to be related to extensive C-S-H carbonation likely due to prolonged times, to high $\mathrm{CO}_{2}$ concentration or a mixture of both III. Ettringite carbonates according to reaction (3) to yield calcium carbonate(s), calcium sulphate(s) and nanocrystalline gibbsite although alumina gel has also been reported to form [15-18]. Calcium carbonate polymorph formation seems to depend upon the carbonation conditions with works reporting aragonite [16,19], vaterite [20], mixtures of vaterite and aragonite [18], calcite [17] and even the three $\mathrm{CaCO}_{3}$ polymorphs depending upon the investigated sample [15]. It is well established that gypsum is formed at high RH values of $\sim 90 \%$ meanwhile bassanite forms at lower RH (e.g., $60-70 \%$ ) $[18,19,21]$. Although older research works referenced alumina gel as a result of AFt (ettringite phase) decomposition [20], recent investigations report it as aluminium hydroxide [15-17]. AFm-type phases, monosulfoaluminates, are also carbonate in a similar way than that of AFt, leading to calcium carbonates, calcium sulphates and nanocrystalline gibbsite/aluminium hydroxide [18]. Finally, the authors are not aware of the works fully devoted to prove the stability of aluminium hydroxide under $\mathrm{CO}_{2}$ atmospheres, see reaction (4). However, from the reports of carbonation of calcium aluminate and sulphoaluminate cement binders [15-17], it could be deduced that $\mathrm{Al}(\mathrm{OH})_{3}$ is not carbonated, which is backed by other publications [22].

Table 1. Carbonation reactions of selected components in hydrated cement binders [7].

\begin{tabular}{cccc}
\hline Component & Chemical Formula & Carbonation Reaction (in $\mathrm{H}_{2} \mathrm{O}$ Presence) & Reaction \\
\hline Portlandite & $\mathrm{Ca}(\mathrm{OH})_{2}$ & $\mathrm{Ca}(\mathrm{OH})_{2}+\mathrm{CO}_{2} \rightarrow \mathrm{CaCO}_{3}{ }^{\#}+\mathrm{H}_{2} \mathrm{O}$ & $(1)$ \\
C-S-H-gel & $(\mathrm{CaO})_{\mathrm{x}} \mathrm{SiO}_{2} \cdot \mathrm{nH}_{2} \mathrm{O}$ & $(\mathrm{CaO})_{1.8} \mathrm{SiO}_{2} \cdot 4 \mathrm{H}_{2} \mathrm{O}+1.8 \mathrm{CO}_{2} \rightarrow 1.8 \mathrm{CaCO}_{3}+\mathrm{SiO}_{2} \cdot \mathrm{nH}_{2} \mathrm{O}+\mathrm{yH}_{2} \mathrm{O}$ & $(2)$ \\
Ettringite, $\mathrm{AFt}$ & $\mathrm{Ca}_{6} \mathrm{Al}_{2}\left(\mathrm{SO}_{4}\right)_{3}(\mathrm{OH})_{12} \cdot 26 \mathrm{H}_{2} \mathrm{O}$ & $\mathrm{AFt}+3 \mathrm{CO}_{2} \rightarrow 3 \mathrm{CaCO}_{3}+3 \mathrm{CaSO}_{4} \cdot \mathrm{mH}_{2} \mathrm{O}^{\$}+2 \mathrm{Al}(\mathrm{OH})_{3}+\mathrm{zH} \mathrm{H}_{2} \mathrm{O}$ & $(3)$ \\
Gibbsite & $\mathrm{Al}(\mathrm{OH})_{3}$ & $\mathrm{Al}(\mathrm{OH})_{3}+\mathrm{CO}_{2} \rightarrow$ stable? & $(4)$ \\
\hline
\end{tabular}

${ }^{\#} \mathrm{CaCO}_{3}$ can precipitate as calcite, aragonite, vaterite, amorphous calcium carbonate(s) or mixtures of these phases. ${ }^{*}$ Calcium silicate hydrate gel composition is variable but close to $\mathrm{x} \sim 1.7-1.9$ and $\mathrm{n} \sim 4.0$ for neat Portland cement pastes [23,24]. ${ }^{\$}$ Calcium sulphate precipitates as gypsum or bassanite depending upon the $\mathrm{RH}$ of the carbonation environment.

As discussed just above, there is an understanding in the precipitation of calcium sulphate forms but there is controversy in the formation of different calcium carbonates. Furthermore, in addition to the three crystalline $\mathrm{CaCO}_{3}$ polymorphs, ACC could also form. It is far from straightforward to disentangle the formation of amorphous phases within these systems, which also contain initial amorphous/nanocrystalline phases like C-S-H gel [25,26] or nano-gibbsite [27-29]. To further study amorphous/nanocrystalline phases, synchrotron total scattering pair distribution function (PDF) methodology $[30,31]$ is an 
ideal tool. Collecting a total scattering data with enough Q-resolution, Rietveld quantitative phase analyses could be carried out in the reciprocal-space and PDF analyses in the directspace. In fact, PDF analyses have been recently carried out for better understanding of the local structure of C-S-H gel which could be satisfactorily explained as a mixture of nanocrystalline defective clinotobermorite and an amorphous component with an atomic local order of few layer-thick calcium hydroxide [23,32,33]. PDF methodology has been recently used for improving our understanding in cement chemistry. In situ synchrotron and neutron PDF were employed to study the hydration of alite and G-type oil well cement including the role of a phosphonate retarder [34]. It was shown that calcium complexation by the retarder was key, with C-S-H gel nuclei poisoning and $\mathrm{CH}$ partial precipitation inhibition also contributing. In situ synchrotron PDF was also employed to study the atomic structural deformation of C-S-H under external loading. The consequences of applied loading were measured by: (i) the strain gauge, (ii) the d-spacing shifts (reciprocal space), and the interatomic distance shifts (real space) [35]. For the $r<20 \AA$ range (in real space), where the C-S-H contribution dominates, a 53-year-old alite paste had a much higher overall elastic modulus than a 131-day-old paste, being 18.3 and $8.3 \mathrm{GPa}$, respectively. PDF can also be used to investigate the alternative sustainable binders which may contain more alkalis [36]. Many sodium-substituted calcium-(alumino-)silicate-hydrate gels were studied and it was shown that the addition of higher levels of alkalis resulted in a systematic reduction of the degree of silicate polymerisation of the gels with clear consequences in their nanoscale ordering.

To the best of the authors knowledge, there are just two papers employing PDF to further study carbonation of cementitious materials. In a first work [37], in situ PDF was employed to investigate the local atomic structural changes occurring during the accelerated carbonation of four types of alkali-activated slag cements. C-A-S-H gel decalcification was shown to proceed in the presence of amorphous calcium carbonate. In addition, it was reported that high $\mathrm{MgO}$ content favours the formation of ACC over calcite or vaterite. In a second work from the same authors [13], in situ PDF was also employed to investigate the changes during the accelerated carbonation of synthetic C-S-H gel. Rietveld analyses firmly stablished the precipitation of vaterite $(\sim 60 \mathrm{wt} \%)$ and calcite $(\sim 40 \mathrm{wt} \%)$. The analysis of the in situ PDF data showed a continuous calcium decalcification of the C-S-H gel and the final products being an amorphous silica-rich decalcified gel. Finally, it is worth underlining that synchrotron PDF has been used to study the local structures of amorphous and crystalline calcium carbonates from organisms [38,39]. Although this work is not directly related to cement binder carbonation, it reports interesting signatures of crystalline and amorphous calcium carbonates in the PDF patterns that can be used for comparative purposes.

In order to contribute to the understanding of the carbonation reactions in cement binders, three reference pastes have been prepared here: (i) ettringite and nano-gibbsite paste from the hydration of ye'elimite with anhydrite; (ii) C-S-H gel with high amount of portlandite from the hydration of $\mathrm{Ca}_{3} \mathrm{SiO}_{5}$; and (iii) C-S-H gel with low amount of portlandite from the hydration of $\mathrm{Ca}_{2} \mathrm{SiO}_{4}$. A fraction of these pastes were carbonated in controlled conditions. The six resulting samples were analysed by synchrotron total scattering, by Rietveld and pair distribution function approaches. Furthermore, thermal analyses were also carried out. The polymorphism of the different forms has been firmly established from high-resolution synchrotron data. It is proved that ettringite decomposed, in the employed experimental conditions, to yield aragonite, bassanite and nano-gibbsite. It is explicitly stated that ACC in not formed. Conversely, the mixtures of C-S-H gel and portlandite gave the three crystalline $\mathrm{CaCO}_{3}$ polymorphs and ACC. The signatures of ACC in the thermal analysis traces are now clearly shown up.

\section{Materials and Methods}

\subsection{Total Scattering Synchrotron X-ray Powder Diffraction}

Synchrotron X-ray powder diffraction (SXRPD) patterns for the six pastes were collected at the X-ray powder diffraction BL04-MSPD beamline at ALBA synchrotron (Barcelona, 
Spain) in Debye-Scherrer (transmission) mode [40]. The wavelength, 0.41318(1) $\AA$, was selected with a double-crystal $\mathrm{Si}$ (111) monochromator and determined by using Si640d NIST standard ( $a=5.43123 \AA$ ). Five patterns were collected for each sample, each lasting $\sim 40 \mathrm{~min}$, and merged in order to improve the signal-to-noise ratio in the recorded very wide angular range, 1 to $130^{\circ}$ (20) (for the employed wavelength, $0.41318 \AA$ ).

\subsubsection{Rietveld Analysis}

Rietveld method using GSAS [41] v.1.8. software was used to perform quantitative phase analysis. A pseudo-Voigt peak shape function with the asymmetry correction included $[42,43]$ was used. The refined overall parameters were: background coefficients, phase scale factors, unit cell parameters, zero-shift error, peak shape parameters and preferred orientation coefficient if needed. The crystal structures used for all phases are given in the Appendix A (Table A1).

\subsubsection{PDF Analysis}

PDFgetX3 software [44] was used to obtain the PDF experimental data with $Q_{\max }=21 \AA^{-1}$. PDFGui software [45] was employed to obtain structural and quantitative phase analysis. Crystalline nickel PDF data were used to determine the instrumental parameters: $\mathrm{Q}_{\mathrm{damp}}=0.036 \AA^{-1}$ and $\mathrm{Q}_{\text {broad }}=0.061 \AA^{-1}$. Final global optimised parameters were: scale factors, the unit cells and atomic displacement parameters (ADPs). For the gibbsite phase, the atomic positional coordinates and the sp diameter (Spd, equivalent spherical diameter of the nanoparticle) were also optimised. Moreover, the delta2 value, low-r correlated motion peak sharpening factor [46,47], was also refined in the low-r region fits.

\subsection{Thermal Analysis (TA)}

Differential thermal analysis (DTA) and thermogravimetric analysis (TGA) measurements for the six pastes were performed in a SDT-Q600 analyser from TA instruments (New Castle, DE). The temperature was varied from room temperature (RT) to $1000^{\circ} \mathrm{C}$ at a heating rate of $10^{\circ} \mathrm{C} / \mathrm{min}$ and with a gas flow speed of $100 \mathrm{~mL} / \mathrm{min}$. Measurements were made in open platinum crucibles under synthetic air flow $\left(80 \% \mathrm{~N}_{2}\right.$ and $20 \%$ of $\left.\mathrm{O}_{2}\right)$. The derivatives of the weight loss (DTG) have also been calculated and given in the figures.

\subsection{Particle Size Distribution (PSD) Analysis}

The particle size distribution of the anhydrous samples was measured by laser diffraction (Malvern MasterSizer S, Malvern, UK) provided with a wet chamber. Powders were previously dispersed in isopropanol using an ultrasonic bath.

\subsection{BET Surface Area Determination}

The specific surface area of the anhydrous samples was measured by multi-point $\mathrm{N}_{2}$ adsorption with a BET (ASAP 2420, Micromeritics, Norcross, GA, USA) instrument.

\subsection{Samples Description}

Three anhydrous samples were employed in this study: (i) A mixture of stoichiometric orthorhombic ye'elimite $\mathrm{Ca}_{4}\left[\mathrm{Al}_{6} \mathrm{O}_{12}\right] \mathrm{SO}_{4}$ [48] with $31.0 \mathrm{wt} \%$ of anhydrite labelled as Y-A; (ii) stoichiometric triclinic tricalcium silicate, $\mathrm{t}-\mathrm{C}_{3} \mathrm{~S}$, which was purchased from Mineral Research Processing (M.R.PRO); and (iii) monoclinic $\beta$-dicalcium silicate, with chemical formula $\mathrm{Ca}_{2} \mathrm{Si}_{0.972} \mathrm{Al}_{0.028} \mathrm{O}_{3.986} ?_{0.014}$ where the symbol ? stands for oxygen vacancies, named as $\beta-C_{2} S$, which was prepared as detailed in [49]. This $\beta$-dicalcium silicate sample also contains 8.4(3) $\mathrm{wt}^{\mathrm{t}} \%$ of $\gamma$-dicalcium silicate. Anhydrite, for sample $\mathrm{Y}-\mathrm{A}$, was prepared by heating bassanite, marketed by BELITH S.P.R.L. (Belgium), at $700{ }^{\circ} \mathrm{C}$ for $1 \mathrm{~h}$. Table 2 gives the particle size distribution details, density and specific surface area of the used anhydrous samples. 
Table 2. Particle size distribution details, density and specific surface data of the employed anhydrous cement samples*.

\begin{tabular}{cccccc}
\hline Materials & $\mathbf{D}_{\mathbf{v}, \mathbf{1 0}}$ & $\mathbf{D}_{\mathbf{v}, \mathbf{5 0}}$ & $\mathbf{D}_{\mathbf{v}, \mathbf{9 0}}$ & $\boldsymbol{\rho}\left(\mathbf{g} / \mathbf{c m}^{\mathbf{3}}\right)$ & $\mathbf{B E T}\left(\mathbf{m}^{2} / \mathbf{g}\right)$ \\
\hline${ }_{\mathrm{o}-}-\mathrm{C}_{4} \mathrm{~A}_{3} \bar{S}$ & 1.3 & 7.1 & 22.1 & $2.61(1)$ & $1.1(1)$ \\
$\mathrm{C} \overline{\mathrm{S}}$ & 1.5 & 10.1 & 42.6 & $2.93(1)$ & $2.6(1)$ \\
$\mathrm{t}-\mathrm{C}_{3} \mathrm{~S}$ & 0.8 & 4.6 & 11.0 & $3.15(1)$ & $1.9(1)$ \\
$\beta-\mathrm{C}_{2} \mathrm{~S}$ & 1.0 & 6.5 & 35.7 & $3.22(1)$ & $1.7(1)$ \\
\hline
\end{tabular}

${ }^{*}$ Cement notation is used here after: $\mathrm{C}=\mathrm{CaO}, \mathrm{S}=\mathrm{SiO}_{2}, \mathrm{~A}=\mathrm{Al}_{2} \mathrm{O}_{3}, \overline{\mathrm{S}}=\mathrm{SO}_{3}, \mathrm{H}=\mathrm{H}_{2} \mathrm{O}$. Therefore, e.g.,: $\mathrm{Ca}_{3} \mathrm{SiO}_{5}$ is termed $\mathrm{C}_{3} \mathrm{~S}$.

\subsection{Hydration and Accelerated Carbonation}

Pastes were prepared by adding deionised water to the solid material to attain water to solid mass ratios (w/s) of 0.85 for $\mathrm{Y}-\mathrm{A}, 0.50$ for $\mathrm{t}-\mathrm{C}_{3} \mathrm{~S}$ and 0.45 for $\beta-\mathrm{C}_{2} \mathrm{~S}$. Y-A paste was manually stirred for $2 \mathrm{~min}$. $\mathrm{t}-\mathrm{C}_{3} \mathrm{~S}$ and $\beta-\mathrm{C}_{2} \mathrm{~S}$ pastes were mechanically stirred at $800 \mathrm{rpm}$ for $90 \mathrm{~s}$ twice, with a stopping time of $30 \mathrm{~s}$ between them. The as-prepared pastes were cast into hermetically closed polytetrafluoroethylene cylinders and rotated at $16 \mathrm{rpm}$ at $20 \pm 1{ }^{\circ} \mathrm{C}$ (see Figure 1). The pastes were demoulded after 3 days for Y-A, $24 \mathrm{~h}$ for $\mathrm{t}-\mathrm{C}_{3} \mathrm{~S}$ and 28 days for $\beta-C_{2} S$ and stored in demineralised water at $20 \pm 1{ }^{\circ} \mathrm{C}$ for 1.5 months for Y-A, 5 months for $t-C_{3} S$ and 12 months for $\beta-C_{2} S$, (see A in Figure 1). The reason for such long hydration times was to have very large degree of hydration for the three pastes. Then, the cylinders were taken out of the water and the surface was gently dried with paper. To prepare the reference samples, the cylinders were ground by hand in an agate mortar, inserted as powder in an Eppendorf and immediately stored in vacuum sealed bags by applying about 0.85 bars within a standard food vacuum sealer unit. The samples were stored in the vacuum-sealed bag up to the day of data collection (see Figure 1). To prepare the carbonated samples, the cylinders were directly stored in vacuum-sealed bags. Prior to the introduction of the samples in the carbonation chamber, the cylinders were ground by hand in an agate mortar. Accelerated carbonation assay was performed for 80 days at $3 \%$ of $\mathrm{CO}_{2}$, at $20^{\circ} \mathrm{C}$ and a fixed $\mathrm{RH}$ of $65 \%$ obtained by a saturated salt solution. The six samples are labelled hereafter: Y-A_hyd, Y-A_carb, $C_{3} S$ S_hyd, $C_{3} S \_c a r b, C_{2} S$ Shyd and $\mathrm{C}_{2} \mathrm{~S} \_$carb. It is important to point out that the non-carbonated samples were kept in sealed bags for 80 days, while the remaining samples were carbonated.

Samples (reference and carbonated) were kept in Eppendorfs in vacuum-sealed bags until total scattering synchrotron X-ray powder diffraction (SXRPD) data collection. Glass capillaries of $0.70 \mathrm{~mm}$ diameter were filled with the powders and sealed with grease to avoid any alteration of the samples.

Finally, in order to discuss the compositions and the weight losses of the hydrated pastes, the hydration reactions must be stated. Hence, the expected product contents, including their ratios, can be calculated. Table 3 reports the most accepted hydration reactions for ye'elimite, alite and belite, which are reactions (5) to (7), respectively. It should be noted that gibbsite and C-S-H are nanocrystalline gels and therefore, their compositions are approximated.

Table 3. Stoichiometries of the hydration reactions for the phases employed in this study $[23,33,50]$.

\begin{tabular}{ccccc}
\hline \multicolumn{2}{c}{ Hydration Reactions, With the Amount of Products in [g/mol] } & Reaction \\
\hline $\mathrm{Ca}_{4}\left[\mathrm{Al}_{6} \mathrm{O}_{12}\right] \mathrm{SO}_{4}+2 \mathrm{CaSO}_{4}+38 \cdot \mathrm{H}_{2} \mathrm{O}$ & $\rightarrow$ & $\mathrm{Ca}_{6} \mathrm{Al}_{2}\left(\mathrm{SO}_{4}\right)_{3}(\mathrm{OH})_{12} \cdot 26 \mathrm{H}_{2} \mathrm{O}[1255.1]+4 \mathrm{Al}(\mathrm{OH})_{3}[312.0]$ & $(5)$ \\
$\mathrm{Ca}_{3} \mathrm{SiO}_{5}+5.2 \mathrm{H}_{2} \mathrm{O}$ & $\rightarrow$ & $(\mathrm{CaO})_{1.8} \mathrm{SiO}_{2} \cdot 4 \mathrm{H}_{2} \mathrm{O}[233.1]+1.2 \mathrm{Ca}(\mathrm{OH})_{2}[88.9]$ & $(6)$ \\
$\mathrm{Ca}_{2} \mathrm{SiO}_{4}+4.2 \mathrm{H}_{2} \mathrm{O}$ & $\rightarrow$ & $(\mathrm{CaO})_{1.8} \mathrm{SiO}_{2} \cdot 4 \mathrm{H}_{2} \mathrm{O}[233.1]+0.2 \mathrm{Ca}(\mathrm{OH})_{2}[14.8]$ & $(7)$ \\
\hline
\end{tabular}




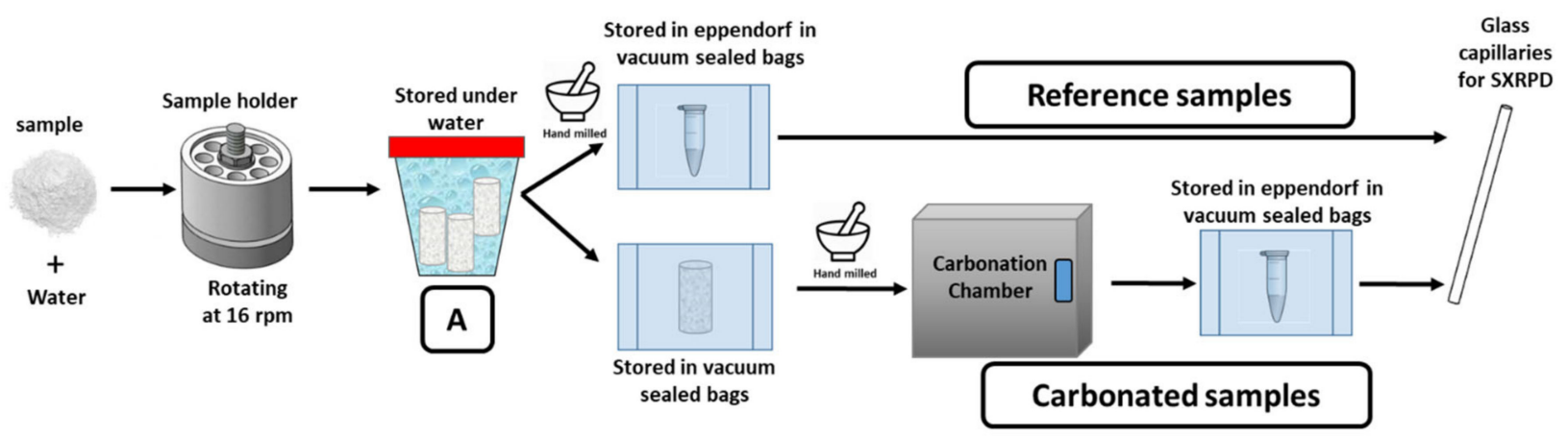

Figure 1. Sketch of the experimental procedure employed to prepare the samples.

\section{Results and Discussion}

The total scattering SXRPD raw data for the six studied samples (Y-A_hyd, Y-A_carb, $\mathrm{C}_{3} \mathrm{~S}$ _hyd, $\mathrm{C}_{3} \mathrm{~S} \_$carb, $\mathrm{C}_{2} \mathrm{~S}$ _hyd and $\mathrm{C}_{2} \mathrm{~S}$ _carb, ) are plotted in Figure 2. It can be seen that the experimental configuration used allow us to obtain, in addition to a large Q-range for PDF analyses, high resolution (in reciprocal space) data which are suitable for Rietveld analysis. Therefore, in a first stage, the low angle regions of these patterns were analysed by the Rietveld method. In a second stage, the full patterns were inspected and analysed by the PDF method. It is noted here that we have recently discussed the different resolutions arising from common synchrotron total scattering experimental configurations [51].

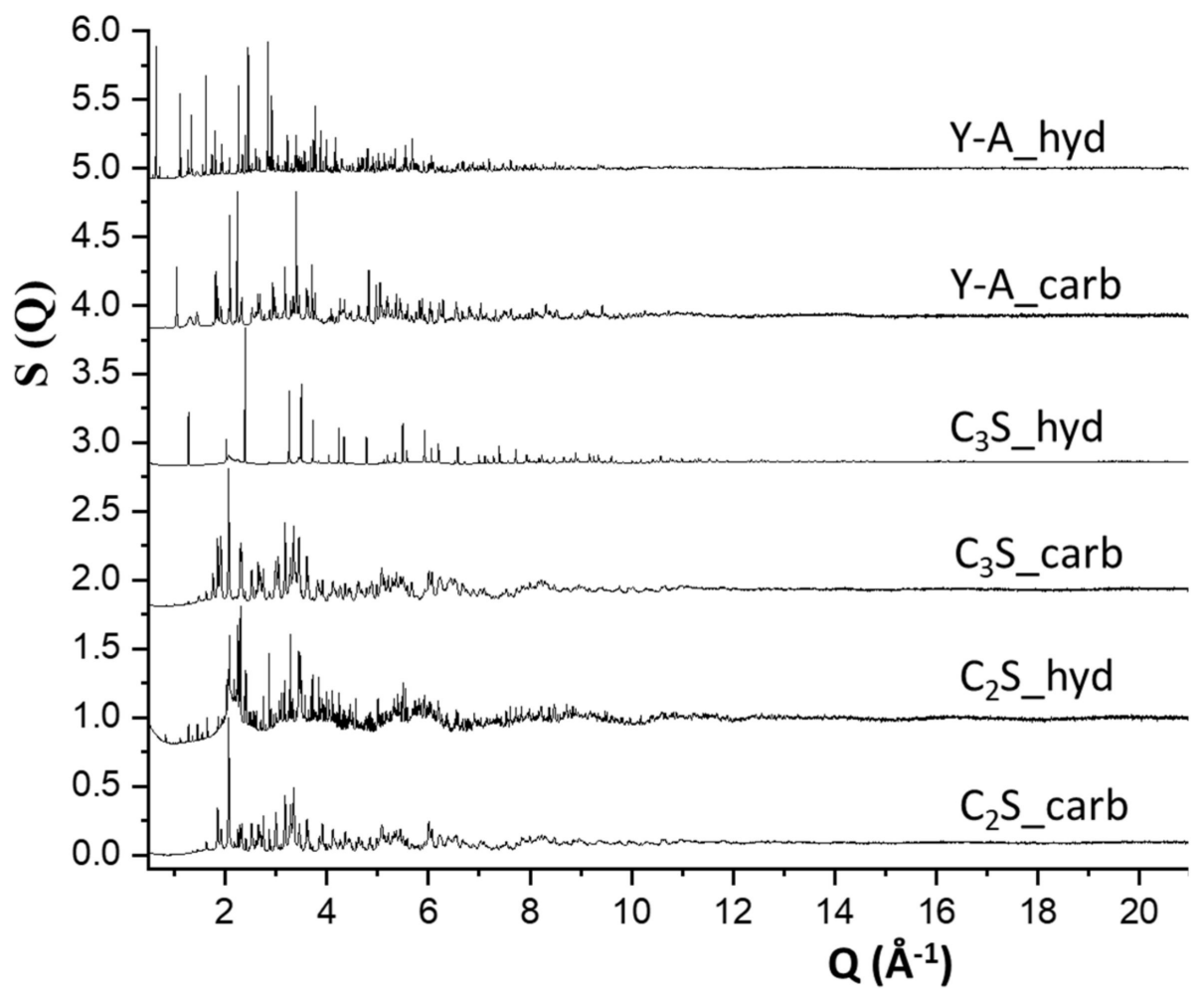

Figure 2. Synchrotron $X$-ray total scattering functions, $S(Q)$, for the studied cement samples. The patterns were normalised with respect to their highest diffraction peaks and vertically displaced for adequate visualisation.

\subsection{Synchrotron Rietveld Quantitative Phase Analysis}

The low angle regions $\left(2-15^{\circ} / 2 \theta\right)$ of the SXRPD patterns were analysed by the Rietveld method as detailed in the experimental section. Figure 3 displays the Rietveld plots for Y-A_hyd and Y-A_carb samples. The Rietveld quantitative phase analysis (RQPA) 
results are reported in Table 4. It has been confirmed that the hydration of ye'elimite and anhydrite yields ettringite as the unique crystalline phase and nanocrystalline gibbsite in agreement with previous publications [27,29]. The crystal structure of gibbsite was not used to fit nano-gibbsite diffraction peaks in this RQPA because they were very broad, see Figure 3. Carbonation of this paste resulted in aragonite, as the only $\mathrm{CaCO}_{3}$ crystalline phase. In agreement with previous reports $[18,19,21]$, only bassanite is observed here, as calcium sulphate crystalline phase, because the $\mathrm{RH}$ of the carbonation experiment was $65 \%$. Furthermore, nanocrystalline gibbsite displayed broad peaks but relatively sharper than those present in Y-A_hyd. Therefore, the crystal structure of this phase was included in the Rietveld fit and the results are shown in Figure 3 and Table 4.
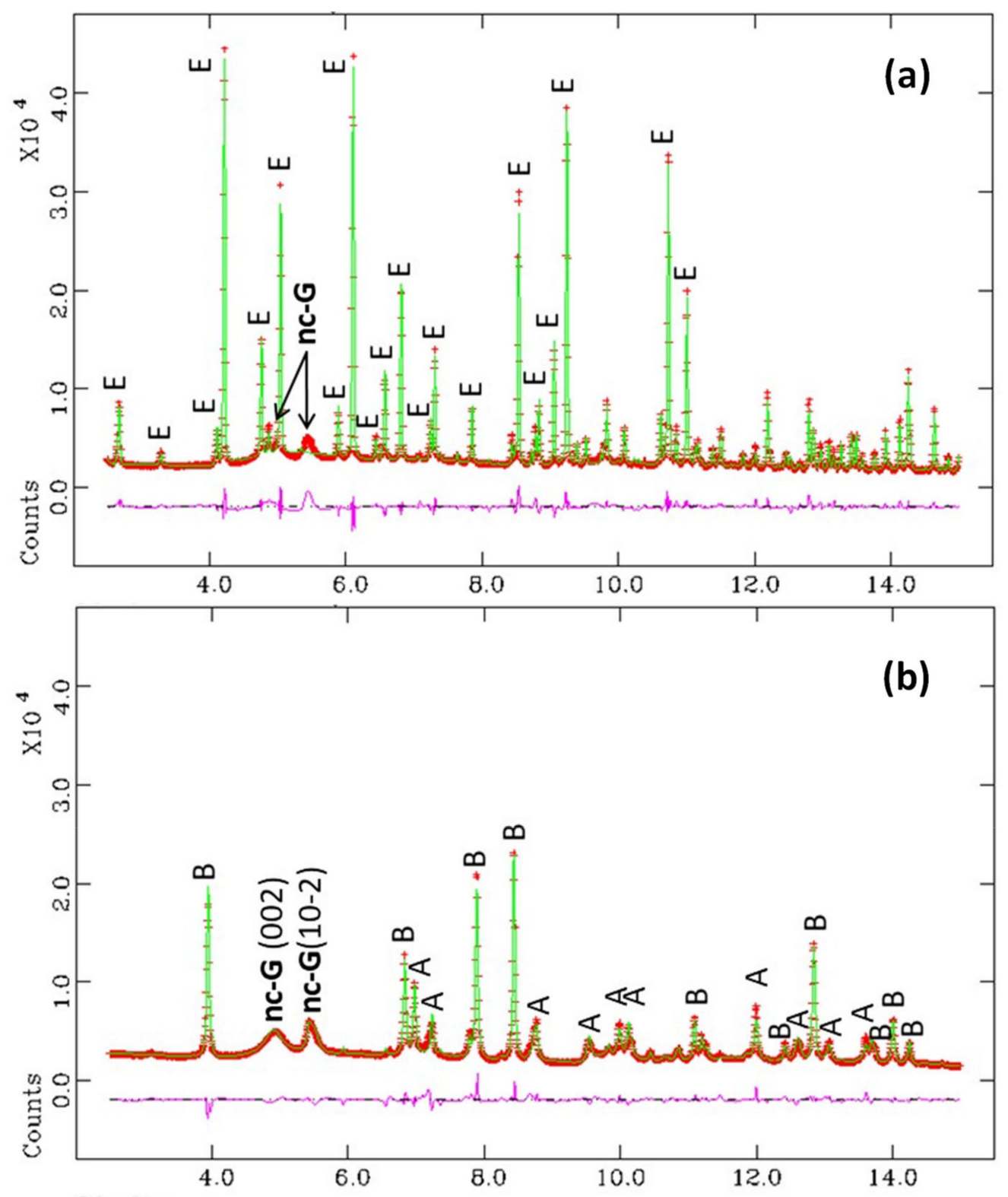

$2 \Theta$, deg

Figure 3. Selected low angle ranges (intensity vs $2 \theta$ ) of the synchrotron Rietveld plots $(\lambda=0.41 \AA)$ for (a) Y-A_hyd, hydrated for 1.5 months and (b) Y-A_carb paste after carbonation for 80 days at 3\% of $\mathrm{CO}_{2}\left(\mathrm{~T}=20^{\circ} \mathrm{C}\right.$ and $\left.\mathrm{RH}=65 \%\right)$. The top pattern contains crystalline ettringite and very broad diffraction peaks of nano-gibbsite. The main peaks are labelled. Top pattern: ettringite (E) and nanocrystalline-gibbsite (nc-G). Bottom pattern: aragonite (A), bassanite (B), nanocrystalline-gibbsite (nc-G) [including their (hkl) indexes]. 
The Rietveld fit for $\mathrm{C}_{3} \mathrm{~S}$ _hyd sample is shown in Figure 4. It can be deduced that this is a high-quality sample as the unhydrated $C_{3} S$ percentage is very low and the sample does not contain crystalline $\mathrm{CaCO}_{3}$ which proves that the sample was properly prepared and stored. The main crystalline phase is portlandite, $93 \%$ of the overall crystalline content, as reported in Table 4 . However, the main component in this sample is nanocrystalline C-S-H gel being $\sim 67 \mathrm{wt} \%$ according to reaction (6) which was not taken into account for the Rietveld quantification due to its nanocrystalline/amorphous nature. When $\mathrm{C}_{3} \mathrm{~S} \_$hyd is carbonated, see experimental section, the three crystalline $\mathrm{CaCO}_{3}$ polymorphs are present in the sample in similar amounts. It should also be noted that the maximum in the background, which arises from the contribution of amorphous phase(s), moved from $\sim 8^{\circ}(\sim 3.05 \AA)$ for $C_{3} S \_$hyd to $\sim 7^{\circ}(\sim 3.5 \AA)$ for $C_{3} S_{-}$carb. The presence of this very large broad hump in carbonated pastes was already reported to be characteristic of amorphous silica gel [52].

Table 4. Results of the Rietveld quantitative phase analyses of the synchrotron X-ray total scattering patterns.

\begin{tabular}{|c|c|c|c|c|c|c|}
\hline Phase (wt\%) & Y-A_hyd & Y-A_carb & $\mathrm{C}_{3} \mathrm{~S}$ _hyd & $\mathrm{C}_{3} \mathrm{~S}_{-}$carb & $\mathrm{C}_{2} \mathrm{~S}_{-}$hyd & $\mathrm{C}_{2} \mathrm{~S}_{-}$carb \\
\hline $\mathrm{t}-\mathrm{C}_{3} \mathrm{~S}$ & - & - & $6.7(1)$ & - & - & - \\
\hline$\beta-C_{2} S$ & - & - & - & - & $55.0(3)$ & $8.1(1)$ \\
\hline$\gamma-C_{2} S$ & - & - & - & - & $28.7(4)$ & - \\
\hline $\mathrm{CH}$ & - & - & 93.3(4) & $0.6(1)$ & $8.7(2)$ & - \\
\hline $\mathrm{AFt}$ & 100.0 & - & - & - & - & - \\
\hline Calcite & - & - & - & $26.8(9)$ & $2.2(2)$ & $43.1(1)$ \\
\hline Vaterite & - & - & - & 34.1(3) & - & $5.9(4)$ \\
\hline Aragonite & - & $23.4(2)$ & - & $38.5(3)$ & - & $42.9(1)$ \\
\hline Bassanite & - & $38.6(1)$ & - & - & - & - \\
\hline Monocarbonate * & - & - & - & - & $5.4(5)$ & - \\
\hline nano-Gibbsite & - & $37.9(9)$ & - & - & - & - \\
\hline
\end{tabular}

The Rietveld fit for $\mathrm{C}_{2} \mathrm{~S}$ _hyd sample was more complicated as shown in Figure 5. After hydration for one year, $55 \mathrm{wt} \%$ of $\beta-C_{2} S$ and $29 w \mathrm{t} \%$ of $\gamma-C_{2} S$ remained unhydrated, see Table 4 , with respect to $100 \%$ of crystalline material. However, it should be noted that the main component in this sample is nanocrystalline C-S-H gel which was not accounted for in this analysis. It must also be highlighted that this sample was partly carbonated with $2.2 \mathrm{wt} \%$ of calcite and $5.4 \mathrm{wt} \%$ of monocarbonate AFm-type phase likely due to the prolonged hydration time. From this study, several results are obtained. First, $\gamma-\mathrm{C}_{2} \mathrm{~S}$ has fully reacted/carbonated. Second, the three crystalline $\mathrm{CaCO}_{3}$ polymorphs are present but the vaterite content is much smaller and the calcite content much higher, when compared to the results obtained for $\mathrm{C}_{3} \mathrm{~S}_{-}$carb. Third, the maximum in the background is again moved from $\sim 8^{\circ}$ for $C_{2} S \_h y d$ to $\sim 7^{\circ}$ for $C_{2} S \_c a r b$, see Figure 5. 


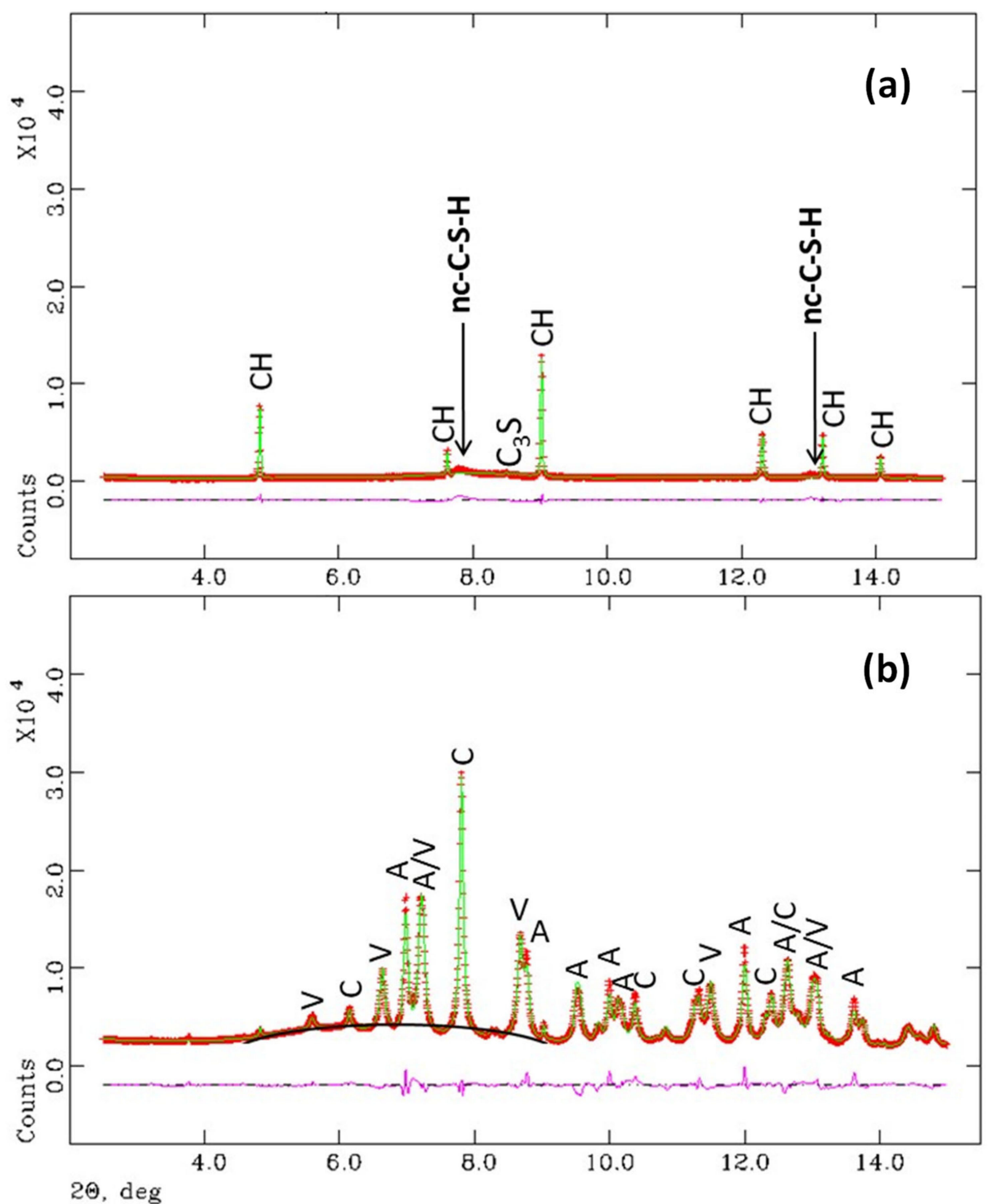

Figure 4. Selected low angle ranges (intensity vs. $2 \theta)$ of the synchrotron Rietveld plots $\left(\lambda=0.41 \AA\right.$ ) for (a) hydrated t- $C_{3} S$ for 5 months and (b) the $\mathrm{C}_{3} \mathrm{~S}$ paste after carbonation for 80 days at $3 \%$ of $\mathrm{CO}_{2}\left(\mathrm{~T}=20^{\circ} \mathrm{C}\right.$ and $\left.\mathrm{RH}=65 \%\right)$. The main peaks are labelled. Top pattern: Portlandite $(\mathrm{CH})$, alite $\left(\mathrm{C}_{3} \mathrm{~S}\right)$ and nanocrystalline C-S-H gel (nc-C-S-H). Bottom pattern: calcite $(\mathrm{C})$, aragonite $(\mathrm{A})$ and vaterite $(\mathrm{V})$. The increase in the background centred at $\sim 7^{\circ} / 2 \theta$ for $\mathrm{C}_{3} \mathrm{~S}_{-}$carb is highlighted. 


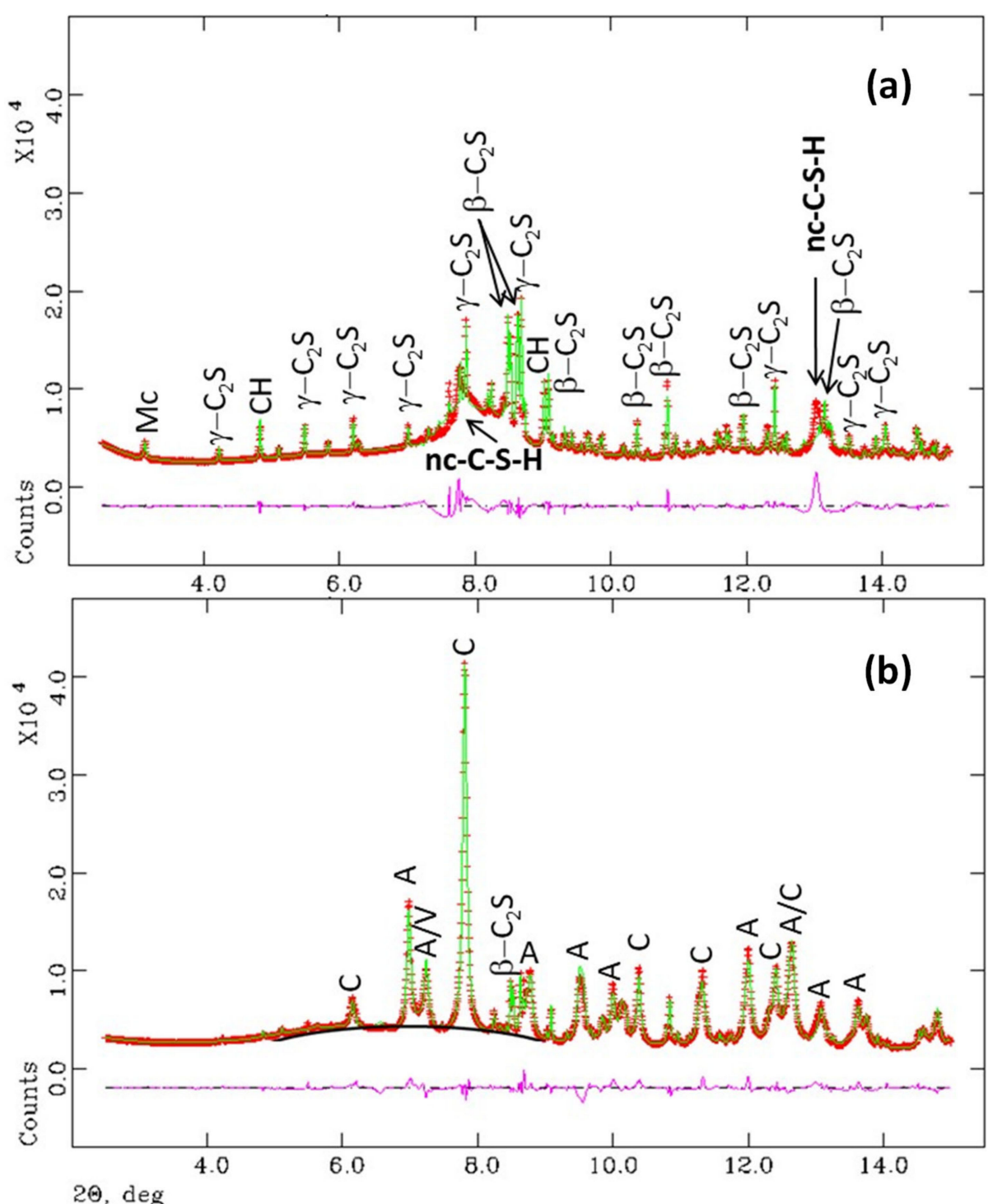

Figure 5. Selected low angle ranges (intensity vs. $2 \theta)$ of the synchrotron Rietveld plots $(\lambda=0.41 \AA)$ for (a) hydrated $\beta-C_{2} S$ for 12 months and (b) the $C_{2} S$ paste after carbonation for 80 days at $3 \%$ of $\mathrm{CO}_{2}\left(\mathrm{~T}=20{ }^{\circ} \mathrm{C}\right.$ and $\left.\mathrm{RH}=65 \%\right)$. Top pattern: $\beta$-belite $\left(\beta-\mathrm{C}_{2} \mathrm{~S}\right), \gamma$-belite $\left(\gamma-\mathrm{C}_{2} \mathrm{~S}\right)$, nanocrystalline $\mathrm{C}$-S-H gel (nc-C-S-H), portlandite $(\mathrm{CH})$ and monocarbonate $(\mathrm{Mc})$. Bottom pattern: $\beta$-belite $\left(\beta-\mathrm{C}_{2} \mathrm{~S}\right)$, calcite $(C)$, aragonite $(A)$ and vaterite $(V)$. The increase in the background centred at $\sim 7^{\circ} / 2 \theta$ for $C_{2} S \_c a r b$ is highlighted.

\subsection{Synchrotron Pair Distribution Function Analysis}

The PDF data were analysed following a multi r-range approach as previously reported $[27,29]$. The high interatomic correlations region, in this case $4.0-6.0 \mathrm{~nm}$ r-range, allows the crystalline phase contents to be determined, meanwhile the low region is used to characterise the atomic ordering in the nanocrystalline/amorphous components. Figure 6a,c displays the high r-range PDF plots for Y-A_hyd and Y-A_carb samples, respectively. The PDF pattern for Y-A_hyd was fitted by using only the crystal structure of ettringite and the final $R_{W}$ value was $30.4 \%$, which confirmed the Rietveld results showing that this was the only crystalline phase. The analogous PDF analysis for Y-A_carb was very satisfactory by using the crystal structures of bassanite and aragonite, $\mathrm{R}_{\mathrm{W}}=23.9 \%$. The last refinement converged to $61 \mathrm{wt} \%$ of bassanite and $39 \mathrm{wt} \%$ of aragonite. This agrees quite well with the Rietveld results reported in Table 3 after removing the nano-gibbsite contribution being 62.3 and $37.7 \mathrm{wt} \%$, respectively. Furthermore, according to the carbonation 
reaction given in Table 1 and without taking into consideration nano-gibbsite, ettringite decomposes to give $59.2 \mathrm{wt} \%$ of bassanite and $40.8 \mathrm{wt} \%$ of $\mathrm{CaCO}_{3}$. The overall agreement is very good and it shows that (i) the analyses are accurate, and (ii) most of the calcium carbonate is precipitated as crystalline aragonite. Then, the low r-range region, $1.6-4.0 \mathrm{~nm}$, was analysed for these two samples. In this case, the crystal structure of gibbsite was added and its Spd parameter was refined as it takes into account the size of the scattering particles. For Y-A_hyd the refinement converged to $S p d=3.2 \mathrm{~nm}$ and the phase contents were 72 and $28 \mathrm{wt} \%$ for ettringite and nano-gibbsite, respectively. The Rw value for this fit was relatively low, $26.0 \%$, and a selected region is shown in Figure $6 \mathrm{~b}$, the lowest r-range. For Y-A_carb the refinement converged to Spd $=4.6 \mathrm{~nm}$ and the phase contents were 34 , 21 and $45 \mathrm{wt} \%$ for bassanite, aragonite and nano-gibbsite, respectively. The fit is shown in Figure $6 \mathrm{~d}$, having $\mathrm{R}_{\mathrm{W}}=29.1 \%$. These values are a bit far from the expected results from the chemical reactions (5) and (3): 39.1, 27.0 and $33.9 \mathrm{wt} \%$ of bassanite, aragonite and gibbsite, respectively, but much closer to the RQPA results reported in Table 4 . We speculate that this could be due to several reasons including that the amorphous $\mathrm{Al}(\mathrm{OH})_{3}$ gel may contain calcium species and not full decomposition of ettringite according to reaction (3). More research is needed to clarify this disagreement. Finally, it is worth noting that the low r-value PDF traces, between 1.5 and $10 \AA$, for these two materials are well justified with the crystalline and nanocrystalline components. Therefore, the amount of any amorphous phase must be quite small. It is highlighted here that the typical broad bands at $\sim 4.0$ and $6.1 \AA$ A of ACC, see below, is not evident in the difference curve of Figure $6 \mathrm{~d}$.
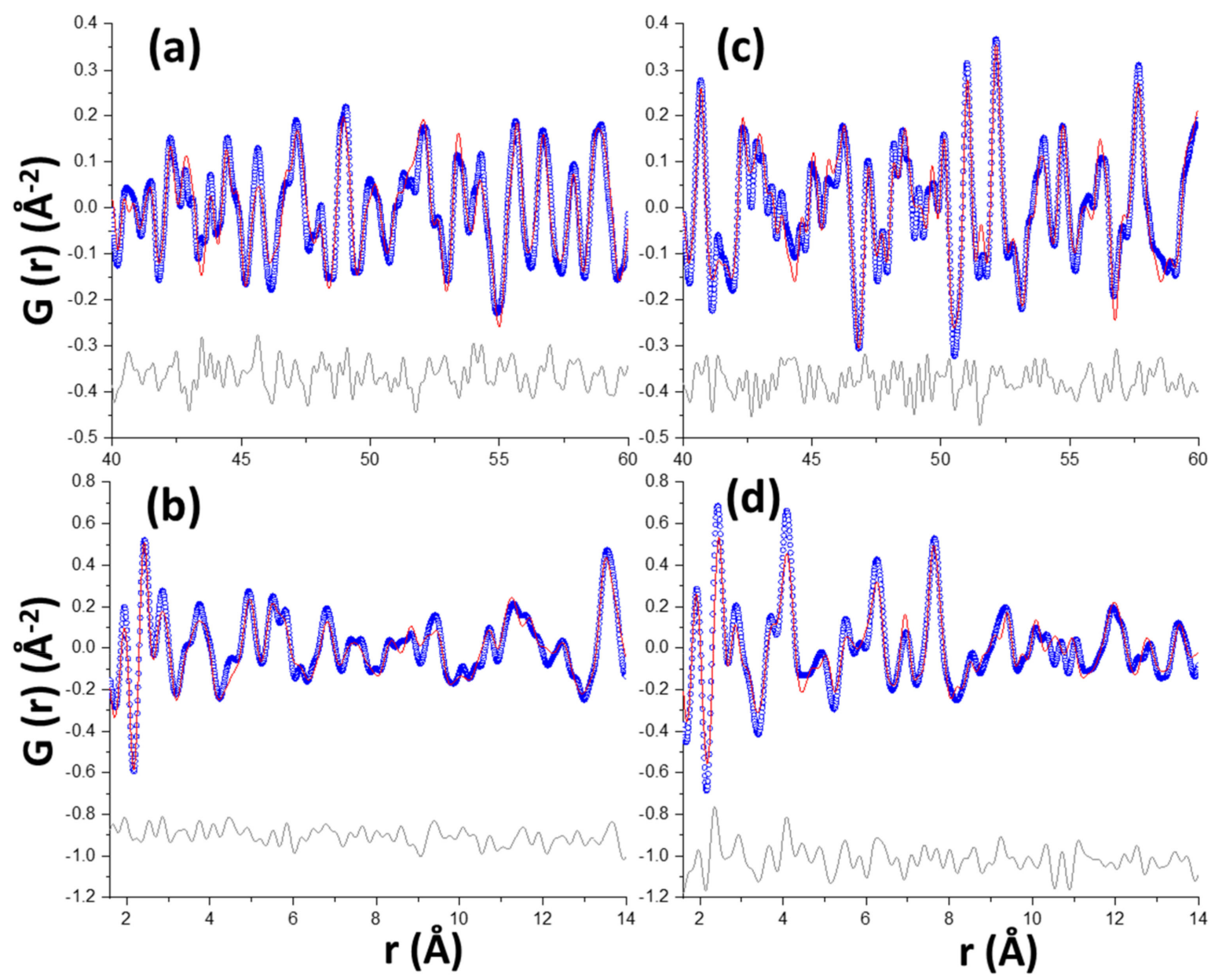

Figure 6. Experimental (blue circles) and fitted (red solid line) PDF patterns for Y-A_hyd: (a,b) panels and Y-A_carb: $(\mathbf{c}, \mathbf{d})$ panels. Difference curves are shown as grey lines at the bottom of each panel. 
The PDF analysis of the $C_{3} S$ and $C_{2} S$ pastes are more complex as the amount of nanocrystalline and amorphous phases are larger and their structural descriptions are still not well established. Figure 7 displays the high r-range results, i.e., the crystalline phases contributions, for these samples. The fit for $\mathrm{C}_{3} \mathrm{~S}$ _hyd is shown in Figure $7 \mathrm{a}$ and the pattern is well justified just with portlandite, $R_{W}=23.3 \%$. The similar analysis for $\mathrm{C}_{3} \mathrm{~S}_{-}$carb, $\mathrm{R}_{\mathrm{W}}=19.1 \%$, gave 44,30 and $26 \mathrm{wt} \%$ for aragonite, vaterite and calcite, respectively; see Figure $7 \mathrm{~b}$. The fit for $\mathrm{C}_{2} \mathrm{~S} \_$hyd is shown in Figure $7 \mathrm{c}$ and it was the poorest with $\mathrm{R}_{\mathrm{W}}=42.4 \%$, indicating problems in the fit are likely due to additional scattering contributions not accounted for. Every attempt to improve this refinement was unsuccessful. The final fit yielded 57,38 and $5 \mathrm{wt} \%$ of $\beta-\mathrm{C}_{2} \mathrm{~S}, \gamma-\mathrm{C}_{2} \mathrm{~S}$ and $\mathrm{CH}$, respectively. The corresponding analysis for $\mathrm{C}_{2} \mathrm{~S}$ _carb was very good, $\mathrm{R}_{\mathrm{W}}=18.5 \%$, resulting in 48,36 and $16 \mathrm{wt} \%$ for aragonite, calcite and $\beta-C_{2} S$, respectively; see Figure $7 \mathrm{~d}$.

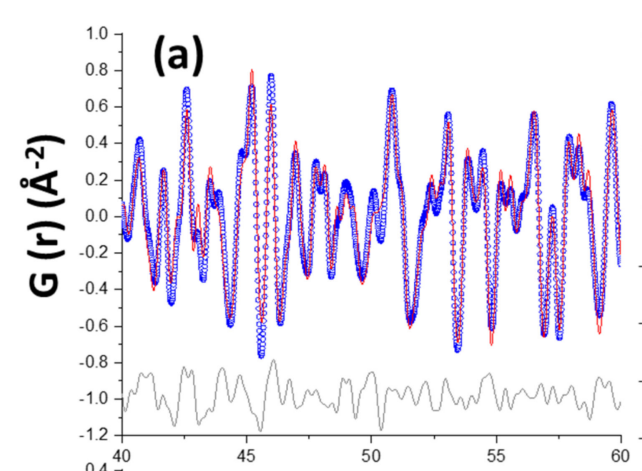

(b)

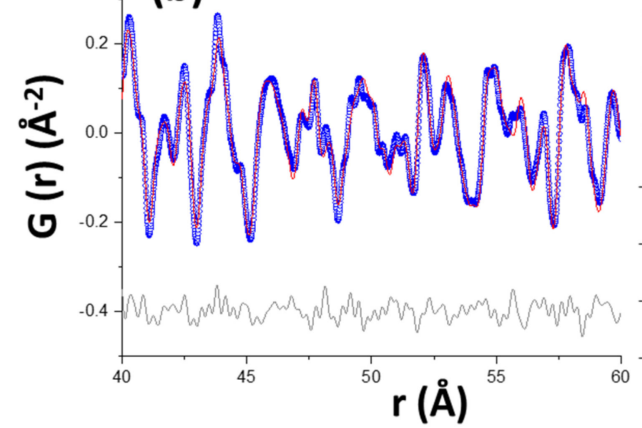

(c)

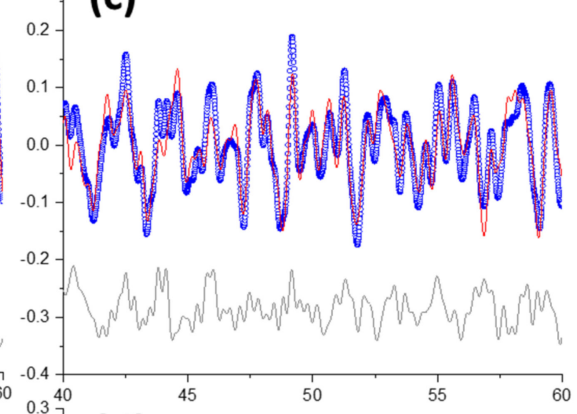

(d)

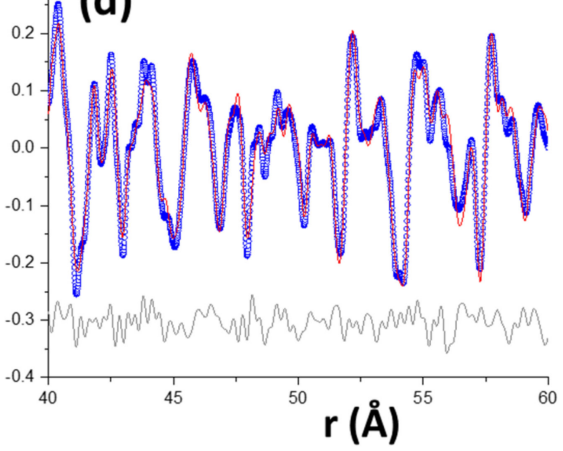

Figure 7. Experimental (blue circles) and fitted (red solid line) large r-range PDF patterns for (a) $\mathrm{C}_{3} \mathrm{~S} \_$hyd, (b) $\mathrm{C}_{3} \mathrm{~S}$ _carb, (c) $\mathrm{C}_{2} \mathrm{~S}$ _hyd and (d) $\mathrm{C}_{2} \mathrm{~S}$ _carb. Difference curves are shown as grey lines at the bottom of each panel.

Now, we turn our attention to the low r-ranges. Due to the lack of structural descriptions for nanocrystalline and amorphous components, we have employed the differential PDF approach $[23,32,53]$. This methodology consists on subtracting from the raw patterns, some known contributions, in this case the ones from the crystalline components. For doing this, the parameters for the crystalline phases (scale, unit cell and atomic displacement parameters) that were refined in the 40-60 ̊ range, are kept fixed in the low PDF region and the difference/subtracted curve corresponds to the contribution of non-crystalline phases (amorphous and nanocrystalline). Hence, Figure 8 shows the low r-range differential PDF

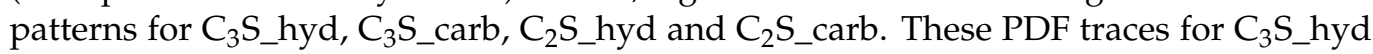
and $\mathrm{C}_{2} \mathrm{~S}$-hyd, Figure $8 \mathrm{a}, \mathrm{c}$, are consistent with the contribution of C-S-H gel and a few layer thick nanoportlandite. This has been extensively discussed very recently and the interested reader is addressed to the publication [23]. The changes in the differential PDF traces for the carbonate materials are readily evident. Very importantly, the key interatomic correlation at $\sim 3.7 \AA$ (which corresponds to Ca $\cdots$ Ca and $\mathrm{Ca} \cdots \mathrm{Si}$ ) in $\mathrm{C}_{3} \mathrm{~S}_{-}$hyd and $\mathrm{C}_{2} \mathrm{~S} \_$hyd, highlighted with broken lines in Figure 8, is almost vanished in $\mathrm{C}_{3} \mathrm{~S}_{-}$carb and $\mathrm{C}_{2} \mathrm{~S}$ _carb. 
This indicated that almost all C-S-H gel in these samples has been carbonated to yield (different forms of) $\mathrm{CaCO}_{3}$ and (probably calcium-containing) $\mathrm{SiO}_{2} \cdot \mathrm{nH}_{2} \mathrm{O}$.

The crystalline products of carbonation reactions (1) and (2) have been already accounted for as detailed above. The products of reactions (1) and (2) that can be amorphous are silica and calcium carbonate. On the one hand, the synchrotron PDF pattern of amorphous silica has been reported $[13,54,55]$. One of the most intense interatomic correlations is located at $1.62 \AA$ and it is due to the Si-O bonds, see Figure $8 \mathrm{~b}, \mathrm{~d}$. There are three additional, less intense peaks, at 2.6, 3.0 and $4.1 \AA$ due to $\mathrm{O} \cdots \mathrm{O}, \mathrm{Si} \cdots \mathrm{Si}$ and second $\mathrm{Si} \cdots \mathrm{O}$ interatomic correlations, respectively. The interatomic distance peak of $\mathrm{O} \cdots \mathrm{O}$ is not labelled in Figure 8 due to its low intensity. The interatomic distance at $1.62 \AA$ is evident but it is typical of any silicate and therefore it cannot be used to disentangle the amorphous silica contribution. However, the second most intense correlation, the $\mathrm{Si} \cdots$ Si distance at $3.0 \AA$ can be used to follow amorphous silica development. This band is partly overlapped with $\mathrm{Ca} \cdots \mathrm{C}$ and $\mathrm{Ca} \cdots \mathrm{O}$ correlations as labelled in Figure 8b,d. Interestingly, $\mathrm{C}_{2} \mathrm{~S}$ _carb has a large $\mathrm{Si} / \mathrm{Ca}$ ratio (due to its stoichiometry) and the band due to the $\mathrm{Si} \cdots \mathrm{Si}$ interatomic correlation is more intense. Additionally, there is scattering in the remaining two real-space distances, at 2.6 and $4.1 \AA$, but the low intensity of the signals does not allow to firmly establish their origin. In any case, although the differential PDF traces do not allow us to unequivocally demonstrate the existence of amorphous silica, the atomic correlations are fully in line with its presence as previously reported for the carbonation of a Portland cement paste $[13,56]$.
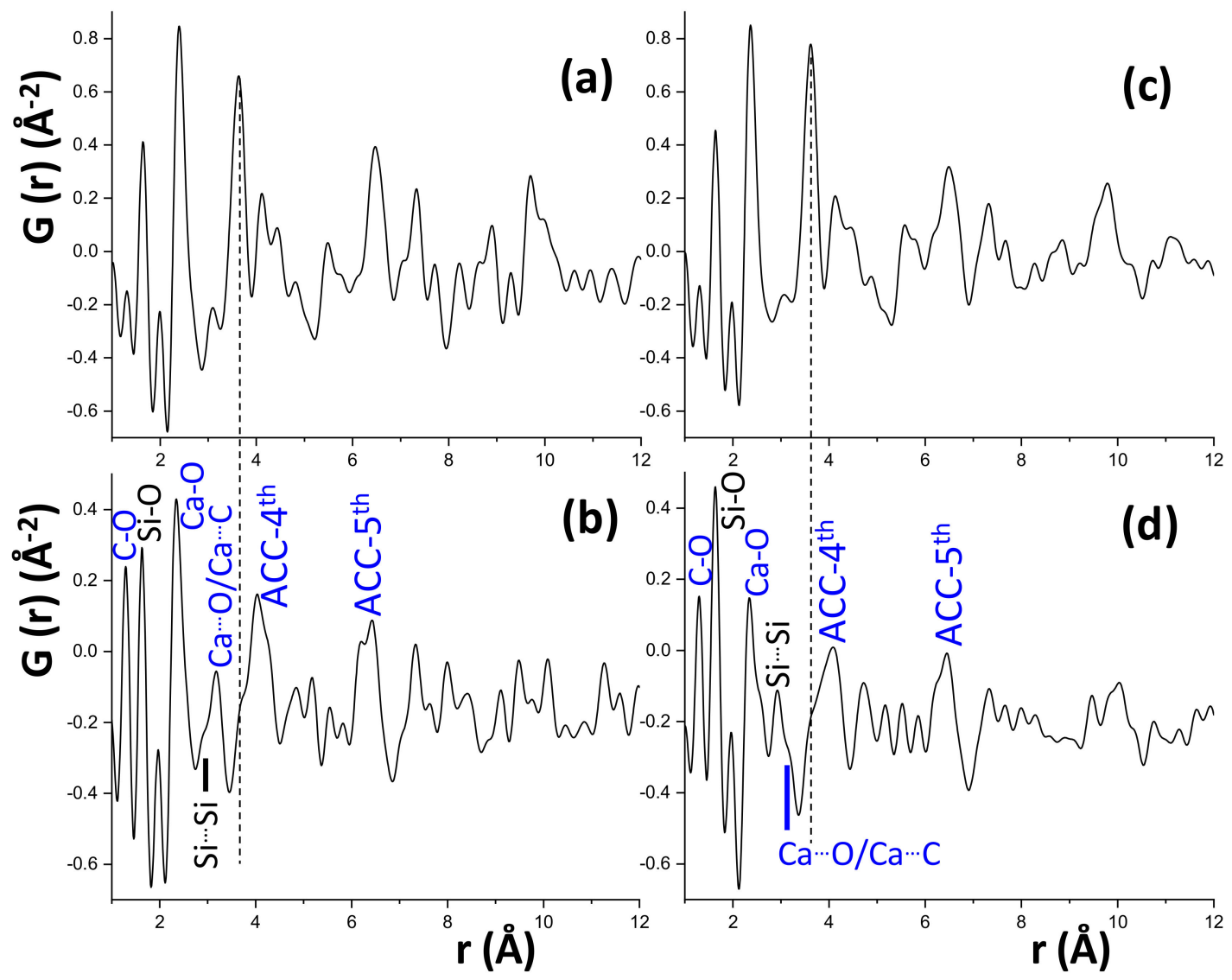

Figure 8. Low r-range differential PDF patterns for (a) $C_{3} S$ _hyd, (b) $C_{3} S$ _carb, (c) $C_{2} S$ _hyd and (d) $C_{2} S$ _carb. These traces display the difference between the raw PDFs patterns and the calculated contributions from the crystalline contents through the fits to the high r-range region as displayed in Figure 7. Therefore, these are the contributions of the nanocrystalline and amorphous phase contents. Prominent peaks due to amorphous silica (black) and amorphous calcium carbonate (blue) are labelled for the carbonated samples. 
On the other hand, the PDF traces of ACC have been extensively studied due to their importance in the biogenesis of calcium carbonate biominerals [38,39]. Although the contributions of the crystalline calcium carbonates have already been subtracted, Figure $8 \mathrm{~b}$,d shows intense (sharp) bands at 1.3 and $2.4 \AA$ typical of any $\mathrm{CaCO}_{3}$ : C-O and $\mathrm{Ca}-\mathrm{O}$ bonds, respectively. This clearly points toward the presence of an ACC in the carbonated samples. Moreover, in addition to the low intensity band at $3.2 \AA$, the PDF

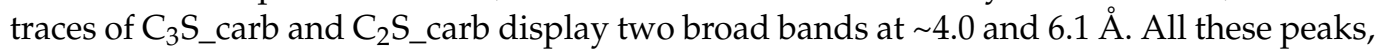
but especially the two broad ones, are the signature of the presence of ACC. Therefore, the presence of amorphous calcium carbonate in $\mathrm{C}_{3} \mathrm{~S}$ _carb and $\mathrm{C}_{2} \mathrm{~S}$ _carb is firmly established from the recorded PDF data by using the differential approach. However, as there is not available structural description, its quantification is still not possible.

\subsection{Thermal Analysis}

Figure 9 shows the thermal analysis results for Y-A_hyd and Y-A_carb. For Y-A_hyd sample, the nominal water added $(\mathrm{w} / \mathrm{c}=0.85)$ should result in an overall weight loss of $46.0 \%$. However, 51.0 is observed and we justify this larger weight loss because the nanocrystalline gibbsite gel can (physically) adsorb water. As expected, carbonation does not take place in this sample, and the absence of a significant weight loss in the $550-800{ }^{\circ} \mathrm{C}$ interval is seen. For the nominal (expected) amount of nano-gibbsite according to reaction (5), $19.9 \%$, should result in an expected weight loss of $7.2 \%$. The measured weight loss in the $175-300{ }^{\circ} \mathrm{C}$ temperature range was $8.3 \%$, slightly larger than expected and in line with the larger nano-gibbsite content measured by PDF and RQPA analyses, see above.

For Y-A_carb sample, the measured contents from PDF were 34.1, 20.7 and $45.2 \%$ for bassanite, aragonite and nano-gibbsite, respectively. The amounts expected from the stoichiometric hydration, followed by the carbonation reaction (3) are: 39.1, 27.0 and 33.9, respectively. These three phases have their respective weight losses that must be normalised taking into account their contents. Hence, the theoretically expected weight losses are $2.4,11.8$ and $11.7 \%$ for bassanite, aragonite and nano-gibbsite, respectively. Again, the overall measured mass loss, $34.3 \%$ is larger than the sum, $25.8 \%$, likely due to the physically absorbed water in the nanocrystalline gel. The carbonate measured weight loss, $9.2 \%$, is smaller than the expected one, $11.8 \%$, pointing towards partial presence of calcium within the $\mathrm{Al}(\mathrm{OH})_{3}$ gel as previously reported [57]. Moreover, it is not possible to rule out the presence of a small proportion of $\mathrm{ACC}$ and/or amorphous $\mathrm{Al}(\mathrm{OH})_{3}$ gel in the carbonated sample. The thermal analysis trace in Figure 9 (bottom) shows a 2.1\% of weight loss in the $550-650{ }^{\circ} \mathrm{C}$ range, which could be related to the decarbonation of ACC. The mass loss in the $160-300{ }^{\circ} \mathrm{C}$ temperature range was $10.4 \%$, slightly less than the expected value, $11.7 \%$. A larger difference is found in the lower temperature range as it could not disentangle the weight loss from bassanite due to the physically absorbed water in the gel. Finally, it is worth noting that the calcium carbonate decomposition is a single endotherm centred at $730^{\circ} \mathrm{C}$.

Concerning the thermal decomposition features of PC pastes, Thiery et al. [58] made two key contributions. On the one hand, using mass spectrometry, they demonstrated that the mass losses above $500{ }^{\circ} \mathrm{C}$ were due to $\mathrm{CO}_{2}$ release and not water. On the other hand, for the calcium carbonate decomposition, they found and reported three modes from the differential TG traces, all coexisting in the ultimate state of carbonation of PC binders. mode I $\left(780{ }^{\circ} \mathrm{C}<\mathrm{T}<990^{\circ} \mathrm{C}\right.$ in their samples) was supposedly associated with the decomposition of well-crystallised calcite. The presence of vaterite and aragonite may cause the carbonates to decompose at lower temperatures, and it could define mode II $\left(700^{\circ} \mathrm{C}<\mathrm{T}<780{ }^{\circ} \mathrm{C}\right)$. Finally, mode III $\left(550^{\circ} \mathrm{C}<\mathrm{T}<700^{\circ} \mathrm{C}\right)$ was tentatively to be associated with amorphous calcium carbonate. 

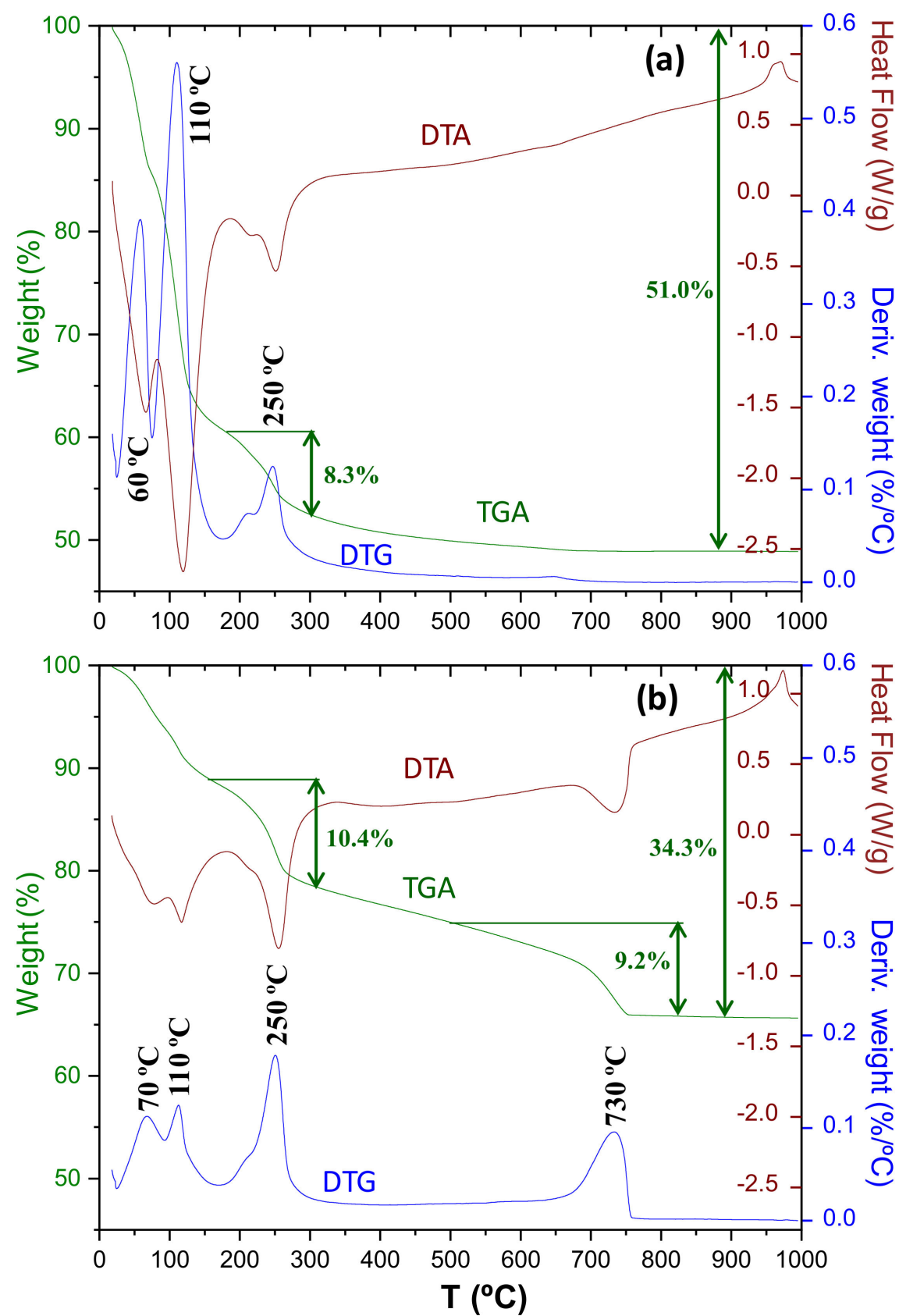

Figure 9. Thermal analysis traces (green: weight losses, blue: derivative of the weight losses and brown: heat flow) for (a) Y-A_hyd, and (b) Y-A_carb. For Y-A_hyd, the reported weight losses 8.3 and $51.0 \%$ were calculated from the temperature ranges $175-300$ and RT-900 ${ }^{\circ} \mathrm{C}$, respectively. For Y-A_carb, the reported weight losses 10.4, 9.2 and $34.3 \%$ were calculated from the temperature ranges $160-310,500-825$ and $\mathrm{RT}-900{ }^{\circ} \mathrm{C}$, respectively.

Figure 10 shows the thermal analysis results for $\mathrm{C}_{3} \mathrm{~S}$ _hyd and $\mathrm{C}_{3} \mathrm{~S}_{-}$carb. For $\mathrm{C}_{3} \mathrm{~S}$ _hyd sample, the nominal water added $(\mathrm{w} / \mathrm{c}=0.50)$ should result in an overall weight loss of $33.3 \%$ which agrees very well with the measured value, $32.9 \%$. Furthermore, carbonation has not taken place, even as ACC, as there is no significant weight loss above $550{ }^{\circ} \mathrm{C}$. The weight loss due to the portlandite, close to $450{ }^{\circ} \mathrm{C}$, was determined from the slope method [59] not taking into account the loss due to C-S-H in the same temperature range. The measured value $5.6 \%$ is slightly smaller than the expected value according to chemical reaction (6), 6.7\%. However, we consider the agreement satisfactory given the approxima- 
tions in the stoichiometry of the reaction and the way in which the experimental value is determined, i.e., the weight loss of this sample between 400 and $550{ }^{\circ} \mathrm{C}$ is $7.0 \%$.
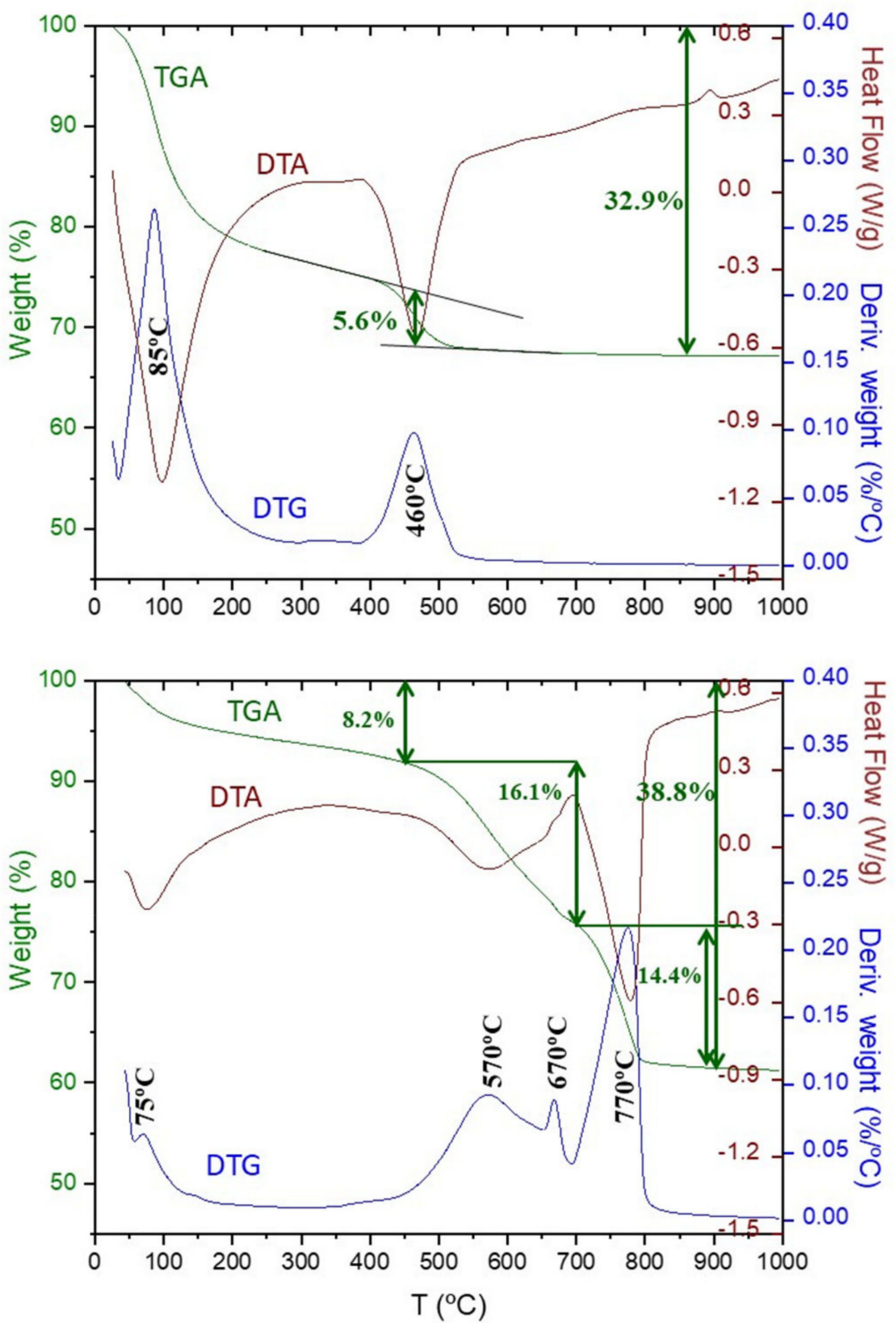

Figure 10. Thermal analysis traces as in Figure 9 for (a) $C_{3} S$ S_hyd and (b) $C_{3} S$ _carb. For $C_{3} S$ _hyd, the reported weight losses 5.6 and $32.9 \%$ were calculated from the slope method centred at $460{ }^{\circ} \mathrm{C}$ (to correct from the C-S-H contribution at these temperatures) and RT-900 ${ }^{\circ} \mathrm{C}$, respectively. For $\mathrm{C}_{3} \mathrm{~S}$ _carb, the reported weight losses $8.2,16.1,14.4$ and $38.8 \%$ were calculated from the temperature ranges RT-450, 450-700, 700-900 and RT-950 ${ }^{\circ} \mathrm{C}$, respectively.

For $\mathrm{C}_{3} \mathrm{~S}$ _carb sample, the first weight loss between $\mathrm{RT}$ and $\sim 450{ }^{\circ} \mathrm{C}, 8.2 \%$ is assigned to the water content of the silica gel and the (likely small) fraction of remaining C-S$\mathrm{H}$ gel. Moreover, the presence of a small amount of free water cannot be discarded in this region. In agreement with the Rietveld content where $\sim 0.6 \mathrm{wt} \%$ of Portlandite 
was measured, no weight loss associated to this phase is observed in the thermal traces. Above $500{ }^{\circ} \mathrm{C}$ two endotherms are observed close to 570 and $770{ }^{\circ} \mathrm{C}$. In the derivative of the weight loss, three peaks of different widths are measured at 570,670 and $770{ }^{\circ} \mathrm{C}$. These three peaks (three $\mathrm{CaCO}_{3}$ decomposition modes) have been widely reported in the cement carbonation bibliography $[12,14,58,60,61]$. The broad endotherm centred at $\sim 570^{\circ} \mathrm{C}$, mode-III, is generally associated to the mass loss from calcium carbonate from the C-S-H gel $[12,14,58]$, which is measured here as $16.1 \%$. This weight loss also contains the mode-II contribution as they are severely overlapped. The relatively sharper endotherm centred here at $\sim 770{ }^{\circ} \mathrm{C}$, mode-I, is associated to the mass loss from the crystalline calcium carbonates, measured as $14.4 \%$. It is noted here that the current accepted knowledge is that both vaterite and aragonite transform on heating to calcite at variable temperatures close to $400-500{ }^{\circ} \mathrm{C}[62,63]$, and therefore, the measured loss in the $700-900{ }^{\circ} \mathrm{C}$ range could correspond to the whole amount of crystalline carbonates. Furthermore, it is currently not known if the ACC phases, in the carbonated pastes, crystallise on heating. A back of the envelop calculation concerning $\mathrm{CaCO}_{3}$ for $\mathrm{C}_{3} \mathrm{~S}_{-}$carb would suggest 1.8 moles from $\mathrm{C}-\mathrm{S}-\mathrm{H}$ and 1.2 moles from $\mathrm{CH}$ according to chemical reaction (6). Hence, assuming full carbonation of both phases (C-S-H to give carbonates with weight losses in the $450-700{ }^{\circ} \mathrm{C}$ temperature range, modes II and III, and $\mathrm{CH}$ to give crystalline carbonates with weight losses at $700-900{ }^{\circ} \mathrm{C}$, mode I) the mass losses should be $60 \%$ and $40 \%$, respectively. The experimental values are $53 \%$ and $47 \%$ showing a relatively good agreement for such unsophisticated calculation. On the other hand, the weight loss for mode-III is too large for being assigned to just amorphous calcium carbonate decomposition. Indeed, more research is needed but the results reported here challenge a commonly accepted understanding that all crystalline $\mathrm{CaCO}_{3}$ decompose above $700{ }^{\circ} \mathrm{C}$.

Figure 11 shows the thermal analysis data for $C_{2} S$ hyd and $C_{2} S_{-}$carb. For $C_{2} S \_$hyd sample, the nominal water added $(\mathrm{w} / \mathrm{c}=0.45)$ should result in an overall weight loss of $31.0 \%$ which agrees fairly well with the measured value, 32.8. This sample is also not carbonated from the atmosphere as the weight loss above $550{ }^{\circ} \mathrm{C}$ is negligible. The weight loss due to the portlandite, close to $420^{\circ} \mathrm{C}$, determined from the slope method was $0.6 \%$. This value is smaller than the expected value according to reaction (7), $1.5 \%$. However, this difference could arise from: (i) The belite hydration degree being lower that $100 \%$ as measured by diffraction; (ii) the experimental errors; and (iii) because the calcium content of the C-S-H gel can be slightly higher than 1.80 as previously reported [23].

For $\mathrm{C}_{2} \mathrm{~S}$ _carb sample, the first weight loss between $\mathrm{RT}$ and $\sim 450{ }^{\circ} \mathrm{C}, 11.2 \%$ is assigned to the water content of the silica gel and also the possible (small) fraction of remaining $\mathrm{C}-\mathrm{S}-\mathrm{H}$ gel. It is underlined here the internal consistency of the obtained results as $\mathrm{C}_{2} \mathrm{~S}_{-}$carb contains more silica gel content than $\mathrm{C}_{3} S_{\text {_carb }}$ and the weight losses in this range were 11.2 and 8.2\%, respectively. As expected, no losses from portlandite is observed in this sample. Above $500{ }^{\circ} \mathrm{C}$, again two endotherms are observed close to 600 and $740{ }^{\circ} \mathrm{C}$, corresponding to modes-III and I, respectively. It is underlined that again mode-II is clearly seen in the DTG trace but not in the DTA one, which suggests that the thermal exchange of that process is very small. From DTG curve and for this sample, $\mathrm{CaCO}_{3}$ decomposition modes-III -II and -I have different widths and are located at 600, 675 and $740{ }^{\circ} \mathrm{C}$, respectively. Mode-III is a very broad endotherm centred at $\sim 600^{\circ} \mathrm{C}$ which has an associated mass loss of $18.5 \%$. This mass loss again contains the mode-II contribution as both effects are strongly overlapped. Mode-I is a broad endotherm centred at $\sim 740^{\circ} \mathrm{C}$ which has an associated mass loss of $6.0 \%$. The ratio between modes III-II and mode I is $75 / 25$. This is in semiquantitative agreement with our hypothesis that the first $\left(\mathrm{CaCO}_{3}\right.$-due $)$ weight loss comes from the C-S-H gel carbonation but not in quantitative agreement as even a lower ratio would be expected for this sample close to $90 / 10$. More research is needed but although the ACC presence is firmly established by differential PDF, the ratio amorphouscrystalline $\mathrm{CaCO}_{3}$ cannot be 3-to-1 as derived from the TA study if the weight loss from $450-700{ }^{\circ} \mathrm{C}$ is considered as arising from the amorphous calcium carbonate content. 

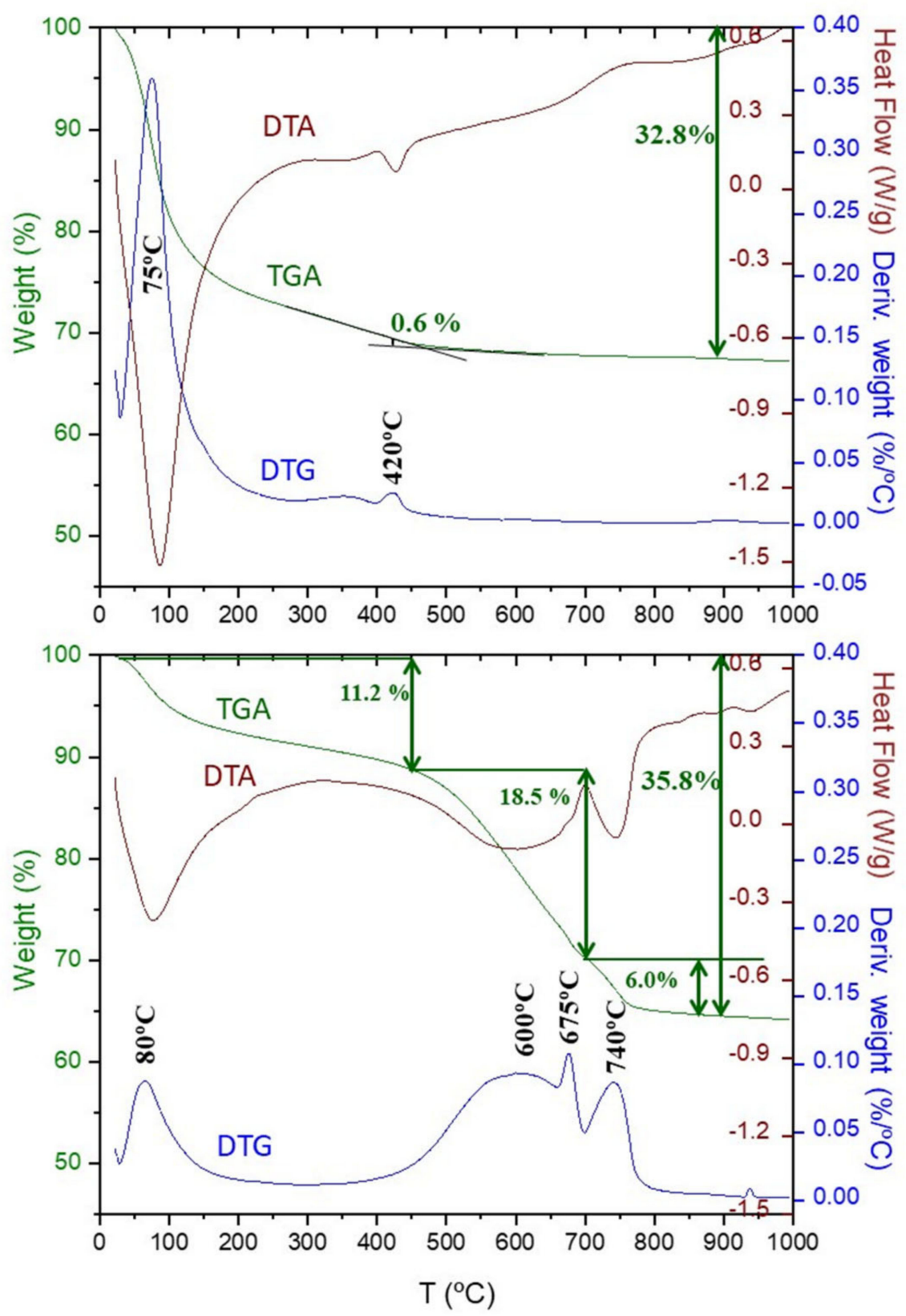

Figure 11. Thermal analysis traces as in Figure 9 for $(\mathbf{a}) C_{2} S$ _hyd and (b) $C_{2} S$ _carb. For $C_{2} S \_h y d$, the reported weight losses 0.6 and $32.8 \%$ were calculated from the slope method centred at $420{ }^{\circ} \mathrm{C}$ (to correct from the C-S-H contribution at these temperatures) and RT-900 ${ }^{\circ} \mathrm{C}$, respectively. For $\mathrm{C}_{2} \mathrm{~S}$ _carb, the reported weight losses $11.2,18.5,6.0$ and $35.8 \%$ were calculated from the temperature ranges RT-450, 450-700, 700-900 and RT-950 ${ }^{\circ} \mathrm{C}$, respectively.

\section{Conclusions}

From the data reported in this work, the following main conclusions can be drawn for the studied reference pastes.

- The reaction of ye'elimite with the stoichiometric amount of anhydrite yields crystalline ettringite and gibbsite with nanocrystalline nature (average particle size $\sim 3 \mathrm{~nm}$ ). After accelerated carbonation $\left(3 \% \mathrm{CO}_{2}\right.$ and $\left.\mathrm{RH}=65 \%\right)$, bassanite, aragonite and gibbsite are formed and quantified. The particle size of gibbsite under these conditions was larger, $\sim 5 \mathrm{~nm}$. Chiefly, PDF analysis indicated that any amorphous content should be low and no appreciable amounts of amorphous calcium carbonate are formed in these experimental conditions. 
- Crystalline $\mathrm{CaCO} 3$ polymorph contents (vaterite, aragonite and calcite) were highly variable in the three studied samples and we still cannot rationalise the conditions for their formation.

- C-S-H carbonates give: (i) amorphous silica gel; (ii) amorphous calcium carbonate, and (iii) variable contents of crystalline calcium carbonates. The existence of both coexisting amorphous components has been firmly established from the differential PDF study, being the most relevant and novel result from this work.

- Carbonate decomposition in the $500-700{ }^{\circ} \mathrm{C}$ temperature range (modes II and III) is intimately joined to C-S-H carbonation. Larger C-S-H content led to larger contribution of the II and III modes. Modes-II and III contain the weight loss from amorphous calcium carbonate but they should also have a contribution from metastable crystalline calcium carbonates (vaterite and aragonite).

Author Contributions: A.C.: conceptualization, methodology, formal analysis, investigation, data curation, writing - original draft, supervision, funding acquisition. A.G.D.l.T.: formal analysis, investigation, writing - review and editing. M.A.G.A.: conceptualization, investigation, writingoriginal draft. All authors have read and agreed to the published version of the manuscript.

Funding: This research was funded by Ministry of Science (Spain), grant number PID2019-104378RJI00, and Junta de Andalucía (Spain), grant number P18-RT-720.

Data Availability Statement: All raw data used in this article (synchrotron patterns and thermal traces) can be freely accessed on Zenodo at https:/ / doi.org/10.5281/zenodo.4607315 (accessed on 13 May 2021), and used under the Creative Commons Attribution license.

Acknowledgments: We thank CELLS-ALBA (Barcelona, Spain) for providing synchrotron beam time at BL04-MSPD and Oriol Vallcorba for his assistance during the experiment. We thank Maurizio Marchi from Italcementi (HeidelbergCement Group) for performing the accelerated carbonation on the hydrated samples.

Conflicts of Interest: The authors declare no conflict of interest.

\section{Appendix A}

Table A1. Crystal structures used in the Rietveld quantitative phase analysis including the ICSD numbers.

\begin{tabular}{ccc}
\hline Phase Name & ICSD & Ref. \\
\hline $\mathrm{t}-\mathrm{C}_{3} \mathrm{~S}$ & 4331 & {$[64]$} \\
$\beta-\mathrm{C}_{2} \mathrm{~S}$ & 81096 & {$[65]$} \\
$\gamma-\mathrm{C}_{2} \mathrm{~S}$ & 81095 & {$[65]$} \\
$\mathrm{CH}$ & 202220 & {$[66]$} \\
$\mathrm{AFt}$ & 155395 & {$[67]$} \\
Calcite & 80869 & {$[68]$} \\
Vaterite & 15879 & {$[69]$} \\
Aragonite & 157994 & {$[70]$} \\
Bassanite & 79529 & {$[71]$} \\
Monocarbonate & 59327 & {$[72]$} \\
nano-Gibbsite & 6162 & {$[73]$} \\
\hline
\end{tabular}

\section{References}

1. World Business Council for Sustainable Development-IEA. Cement Technology Roadmap 2009: Carbon Emissions Reductions up to 2050; OECD Publishing: Paris, France, 2009.

2. UN Environment; Scrivener, K.L.; John, V.M.; Gartner, E. Eco-efficient cements: Potential, economically viable solutions for a low- $\mathrm{CO}_{2}$, cement-based materials industry. Cem. Concr. Res. 2018, 114, 2-26. [CrossRef]

3. Krausmann, F.; Wiedenhofer, D.; Lauk, C.; Haas, W.; Tanikawa, H.; Fishman, T.; Miatto, A.; Schandl, H.; Haberl, H. Global socioeconomic material stocks rise 23-fold over the 20th century and require half of annual resource use. Proc. Natl. Acad. Sci. USA 2017, 114, 1880-1885. [CrossRef]

4. Akhtar, A.; Sarmah, A.K. Construction and demolition waste generation and properties of recycled aggregate concrete: A global perspective. J. Clean. Prod. 2018, 186, 262-281. [CrossRef] 
5. Wu, H.; Zuo, J.; Zillante, G.; Wang, J.; Yuan, H. Construction and demolition waste research: A bibliometric analysis. Archit. Sci. Rev. 2019, 62, 354-365. [CrossRef]

6. Torgal, F.P.; Miraldo, S.; Labrincha, J.A.; de Brito, J. An overview on concrete carbonation in the context of eco-efficient construction: Evaluation, use of SCMs and/or RAC. Constr. Build. Mater. 2012, 36, 141-150. [CrossRef]

7. Šavija, B.; Lukovic, M. Carbonation of cement paste: Understanding, challenges, and opportunities. Constr. Build. Mater. 2016, 117, 285-301. [CrossRef]

8. Ashraf, W. Carbonation of cement-based materials: Challenges and opportunities. Constr. Build. Mater. 2016, 120, 558-570. [CrossRef]

9. Black, L.; Breen, C.; Yarwood, J. Structural features of C-S-H(I) and its carbonation in air-A raman spectroscopic study. Part II: Carbonated phases. J. Am. Ceram. Soc. 2007, 917, 908-917. [CrossRef]

10. Castellote, M.; Andrade, C.; Turrillas, X.; Campo, J.; Cuello, G.J. Accelerated carbonation of cement pastes in situ monitored by neutron diffraction. Cem. Concr. Res. 2008, 38, 1365-1373. [CrossRef]

11. Castellote, M.; Fernandez, L.; Andrade, C.; Alonso, C. Chemical changes and phase analysis of OPC pastes carbonated at different $\mathrm{CO}_{2}$ concentrations. Cem. Concr. Res. 2009, 42, 515-525. [CrossRef]

12. Morandeau, A.; Thiéry, M.; Dangla, P. Investigation of the carbonation mechanism of $\mathrm{CH}$ and C-S-H in terms of kinetics, microstructure changes and moisture properties. Cem. Concr. Res. 2014, 56, 153-170. [CrossRef]

13. Morandeau, A.E.; White, C.E. In situ X-ray pair distribution function analysis of accelerated carbonation of a synthetic calciumsilicate-hydrate gel. J. Mater. Chem. A 2015, 3, 8597-8605. [CrossRef]

14. Saillio, M.; Baroghel-Bouny, V.; Pradelle, S.; Bertin, M.; Vincent, J.; d’Espinose de Lacaillerie, J.-B. Effect of supplementary cementitious materials on carbonation of cement pastes. Cem. Concr. Res. 2021, 142, 106358. [CrossRef]

15. Fernández-Carrasco, L.; Torréns-Martín, D.; Martínez-Ramírez, S. Carbonation of ternary building cementing materials. Cem. Concr. Compos. 2012, 34, 1180-1186. [CrossRef]

16. Martínez-Ramírez, S.; Fernández-Carrasco, L. Carbonation of ternary cement systems. Constr. Build. Mater. 2012, $27,313-318$. [CrossRef]

17. Hargis, C.W.; Lothenbach, B.; Müller, C.J.; Winnefeld, F. Carbonation of calcium sulfoaluminate mortars. Cem. Concr. Compos. 2017, 80, 123-134. [CrossRef]

18. Chen, B.; Horgnies, M.; Huet, B.; Morin, V.; Johannes, K.; Kuznik, F. Comparative kinetics study on carbonation of ettringite and meta-ettringite based materials. Cem. Concr. Res. 2020, 137, 106209. [CrossRef]

19. Nishikawa, T.; Suzuki, K.; Ito, S.; Sato, K.; Takebe, T. Decomposition of synthesized ettringite by carbonation. Cem. Concr. Res. 1992, 22, 6-14. [CrossRef]

20. Zhou, Q.; Glasser, F.P. Kinetics and mechanism of the carbonation of ettringite. Adv. Cem. Res. 2000, 12, 131-136. [CrossRef]

21. Grounds, T.; Midgley, H.G.; Novell, D.V. Carbonation of ettringite by atmospheric carbon dioxide. Thermochim. Acta 1988, 135, 347-352. [CrossRef]

22. Jiang, Y.F.; Liu, C.L.; Xue, J.; Li, P.; Yu, J.G. Insights into the polymorphic transformation mechanism of aluminum hydroxide during carbonation of potassium aluminate solution. CrystEngComm 2018, 20, 1431-1442. [CrossRef]

23. Cuesta, A.; Santacruz, I.; de la Torre, A.G.; Dapiaggi, M.; Zea-Garcia, J.D.; Aranda, M.A.G. Local structure and Ca/Si ratio in C-S-H gels from hydration of blends of tricalcium silicate and silica fume. Cem. Concr. Res. 2021, 143, 106405. [CrossRef]

24. Taylor, H.F.W. Cement Chemistry, 2nd ed.; Thomas Telford Pub: London, UK, 1997; ISBN 9780727725929.

25. Skinner, L.B.; Chae, S.R.; Benmore, C.J.; Wenk, H.R.; Monteiro, P.J.M. Nanostructure of Calcium Silicate Hydrates in Cements. Phys. Rev. Lett. 2010, 104, 195502. [CrossRef] [PubMed]

26. White, C.E. Effects of temperature on the atomic structure of synthetic calcium-silicate-deuterate gels: A neutron pair distribution function investigation. Cem. Concr. Res. 2016, 79, 93-100. [CrossRef]

27. Cuesta, A.; Zea-Garcia, J.D.; Londono-Zuluaga, D.; de la Torre, A.G.; Santacruz, I.; Vallcorba, O.; Aranda, M.A.G. Synchrotron radiation pair distribution function analysis of gels in cements. Crystals 2017, 7, 317. [CrossRef]

28. Cuesta, A.; Ichikawa, R.; Londono-Zuluaga, D.; de la Torre, A.G.; Santacruz, I.; Turrillas, X.; Aranda, M.A.G. Aluminum hydroxide gel characterization within a calcium aluminate cement paste by combined Pair Distribution Function and Rietveld analyses. Cem. Concr. Res. 2017, 96, 1-12. [CrossRef]

29. Cuesta, A.; Zea-Garcia, J.D.; De la Torre, A.G.; Santacruz, I.; Aranda, M.A.G. Synchrotron pair distribution function analyses of ye'elimite-based pastes. Adv. Cem. Res. 2019, 31, 138-146. [CrossRef]

30. Egami, T.; Billinge, S.J.L. Underneath the Bragg Peaks: Structural Analysis of Complex Materials, 2nd ed.; Elsevier Science, Pergamon: Amsterdam, The Netherlands, 2012; ISBN 9780080971414.

31. Billinge, S.J.L.; Kanatzidis, M.G. Beyond crystallography: The study of disorder, nanocrystallinity and crystallographically challenged materials with pair distribution functions. Chem. Commun. 2004, 7, 749. [CrossRef]

32. Grangeon, S.; Fernandez-Martinez, A.; Baronnet, A.; Marty, N.; Poulain, A.; Elkaïm, E.; Roosz, C.; Gaboreau, S.; Henocq, P.; Claret, F. Quantitative X-ray pair distribution function analysis of nanocrystalline calcium silicate hydrates: A contribution to the understanding of cement chemistry. J. Appl. Crystallogr. 2017, 50, 14-21. [CrossRef] [PubMed]

33. Cuesta, A.; Zea-Garcia, J.D.; Londono-Zuluaga, D.; De la Torre, A.G.; Santacruz, I.; Vallcorba, O.; Dapiaggi, M.; Sanfélix, S.G.; Aranda, M.A.G. Multiscale understanding of tricalcium silicate hydration reactions. Sci. Rep. 2018, 8, 8544. [CrossRef] 
34. Kupwade-Patil, K.; Boul, P.J.; Rasner, D.K.; Everett, S.M.; Proffen, T.; Page, K.; Ma, D.; Olds, D.; Thaemlitz, C.J.; Büyüköztürk, O. Retarder effect on hydrating oil well cements investigated using in situ neutron/X-ray pair distribution function analysis. Cem. Concr. Res. 2019, 126, 105920. [CrossRef]

35. Bae, S.; Jee, H.; Suh, H.; Kanematsu, M.; Shiro, A.; Machida, A.; Watanuki, T.; Shobu, T.; Morooka, S.; Geng, G.; et al. Analysis of atomistic structural deformation characteristics of calcium silicate hydrate in 53-year-old tricalcium silicate paste using atomic pair distribution function. Constr. Build. Mater. 2020, 237, 117714. [CrossRef]

36. Garg, N.; Özçelik, V.O.; Skibsted, J.; White, C.E. Nanoscale ordering and depolymerization of calcium silicate hydrates in the presence of alkalis. J. Phys. Chem. C 2019, 123, 24873-24883. [CrossRef]

37. Morandeau, A.E.; White, C.E. Role of magnesium-stabilized amorphous calcium carbonate in mitigating the extent of carbonation in alkali-activated slag. Chem. Mater. 2015, 27, 6625-6634. [CrossRef]

38. Tobler, D.J.; Rodriguez-Blanco, J.D.; Dideriksen, K.; Bovet, N.; Sand, K.K.; Stipp, S.L.S. Citrate effects on amorphous calcium carbonate (ACC) structure, stability, and crystallization. Adv. Funct. Mater. 2015, 25, 3081-3090. [CrossRef]

39. Tobler, D.J.; Rodriguez Blanco, J.D.; Sørensen, H.O.; Stipp, S.L.S.; Dideriksen, K. Effect of pH on Amorphous Calcium Carbonate Structure and Transformation. Cryst. Growth Des. 2016, 16, 4500-4508. [CrossRef]

40. Fauth, F.; Peral, I.; Popescu, C.; Knapp, M. The New Material Science Powder Diffraction beamline at ALBA Synchrotron; Cambridge University Press: Cambridge, UK, 2013; Volume 28, pp. S360-S370.

41. Larson, A.C.; von Dreele, R.B. General structure analysis system (GSAS). Los Alamos Natl. Lab. Rep. LAUR 2004, 748, 86-748.

42. Thompson, P.; Cox, D.E.; Hastings, J.B. Rietveld Refinement of Debye-Scherrer Synchrotron X-ray data from A1203. J. Appl. Crystallogr. 1987, 20, 79-83. [CrossRef]

43. Finger, L.W.; Cox, D.E.; Jephcoat, A.P. Correction for powder diffraction peak asymmetry due to axial divergence. J. Appl. Crystallogr. 1994, 27, 892-900. [CrossRef]

44. Juhas, P.; Davis, T.; Farrow, C.L.; Billinge, S.J.L. PDFgetX3: A rapid and highly automatable program for processing powder diffraction data into total scattering pair distribution functions. J. Appl. Crystallogr. 2013, 46, 560-566. [CrossRef]

45. Farrow, C.L.; Juhas, P.; Liu, J.W.; Bryndin, D.; Božin, E.S.; Bloch, J.; Proffen, T.; Billinge, S.J.L. PDFfit2 and PDFgui: Computer programs for studying nanostructure in crystals. J. Phys. Condens. Matter 2007, 19, 335219. [CrossRef]

46. Jeong, I.K.; Proffen, T.; Mohiuddin-Jacobs, F.; Billinge, S.J.L. Measuring correlated atomic motion using X-ray diffraction. J. Phys. Chem. C 1999, 103, 921-924. [CrossRef]

47. Jeong, I.K.; Heffner, R.H.; Graf, M.J.; Billinge, S.J.L. Lattice dynamics and correlated atomic motion from the atomic pair distribution function. Phys. Rev. B Condens. Matter Mater. Phys. 2003, 67, 104301. [CrossRef]

48. Cuesta, A.; de la Torre, A.G.; Losilla, E.R.; Peterson, V.K.; Rejmak, P.; Ayuela, A.; Frontera, C.; Aranda, M.A.G. Structure, atomistic simulations, and phase transition of stoichiometric yeelimite. Chem. Mater. 2013, 25, 1680-1687. [CrossRef]

49. Cuesta, A.; Aranda, M.A.G.; Sanz, J.; de la Torre, A.G.; Losilla, E.R. Mechanism of stabilization of dicalcium silicate solid solution with aluminium. Dalt. Trans. 2014, 43, 2176-2182. [CrossRef]

50. Cuesta, A.; Álvarez-Pinazo, G.; Sanfélix, S.G.; Peral, I.; Aranda, M.A.G.; De la Torre, A.G. Hydration mechanisms of two polymorphs of synthetic ye'elimite. Cem. Concr. Res. 2014, 63, 127-136. [CrossRef]

51. Zea-Garcia, J.D.; De la Torre, A.G.; Aranda, M.A.G.; Cuesta, A. A Comparative study of experimental configurations in synchrotron pair distribution function. Materials 2019, 12, 1347. [CrossRef] [PubMed]

52. Kangni-Foli, E.; Poyet, S.; Le Bescop, P.; Charpentier, T.; Bernachy-Barbé, F.; Dauzères, A.; L'Hôpital, E.; d'Espinose de Lacaillerie, J.-B. Carbonation of model cement pastes: The mineralogical origin of microstructural changes and shrinkage. Cem. Concr. Res. 2021, 144, 106446. [CrossRef]

53. White, C.E.; Daemen, L.L.; Hartl, M.; Page, K. Intrinsic differences in atomic ordering of calcium (alumino) silicate hydrates in conventional and alkali-activated cements. Cem. Concr. Res. 2015, 67, 66-73. [CrossRef]

54. Ohara, K.; Tominaka, S.; Yamada, H.; Takahashi, M.; Yamaguchi, H.; Utsuno, F.; Umeki, T.; Yao, A.; Nakada, K.; Takemoto, M.; et al. Time-resolved pair distribution function analysis of disordered materials on beamlines BL04B2 and BL08W at SPring-8. J. Synchrotron Radiat. 2018, 25, 1627-1633. [CrossRef] [PubMed]

55. Biswas, R.K.; Khan, P.; Mukherjee, S.; Mukhopadhyay, A.K.; Ghosh, J.; Muraleedharan, K. Study of short range structure of amorphous Silica from PDF using Ag radiation in laboratory XRD system, RAMAN and NEXAFS. J. Non. Cryst. Solids 2018, 488, 1-9. [CrossRef]

56. Borges, P.H.R.; Costa, J.O.; Milestone, N.B.; Lynsdale, C.J.; Streatfield, R.E. Carbonation of CH and C-S-H in composite cement pastes containing high amounts of BFS. Cem. Concr. Res. 2010, 40, 284-292. [CrossRef]

57. Cuesta, A.; De la Torre, A.G.; Santacruz, I.; Trtik, P.; da Silva, J.C.; Diaz, A.; Holler, M.; Aranda, M.A.G. Chemistry and mass density of aluminum hydroxide gel in eco-cements by ptychographic X-ray computed tomography. J. Phys. Chem. C 2017, 121, 3044-3054. [CrossRef]

58. Thiery, M.; Villain, G.; Dangla, P.; Platret, G. Investigation of the carbonation front shape on cementitious materials: Effects of the chemical kinetics. Cem. Concr. Res. 2007, 37, 1047-1058. [CrossRef]

59. Lothenbach, B.; Durdzinski, P.; de Weerdt, K. Thermogravimetric analysis. In A Practical Guide to Microstructural Analysis of Cementitious Materials; Scrivener, K., Snellings, R., Lothenbach, B., Eds.; CRC Press: Boca Raton, FL, USA, 2016; pp. 177-211, ISBN 9781498738675. 
60. Shah, V.; Scrivener, K.L.; Bhattacharjee, B.; Bishnoi, S. Changes in microstructure characteristics of cement paste on carbonation. Cem. Concr. Res. 2018, 109, 184-197. [CrossRef]

61. Thiery, M.; Dangla, P.; Belin, P.; Habert, G.; Roussel, N. Carbonation kinetics of a bed of recycled concrete aggregates: A laboratory study on model materials. Cem. Concr. Res. 2013, 46, 50-65. [CrossRef]

62. Koga, N.; Kasahara, D.; Kimura, T. Aragonite crystal growth and solid-state aragonite-calcite transformation: A physicogeometrical relationship via thermal dehydration of included water. Cryst. Growth Des. 2013, 13, 2238-2246. [CrossRef]

63. Chakoumakos, B.C.; Pracheil, B.M.; Koenigs, R.P.; Bruch, R.M.; Feygenson, M. Empirically testing vaterite structural models using neutron diffraction and thermal analysis. Sci. Rep. 2016, 6, 1-8. [CrossRef]

64. Golovastikov, N.I.; Matveeva, R.G.; Belov, N.V. Crystal structure of the tricalcium silicate $\left(\mathrm{CaOSi}_{2}\right)_{3}=\mathrm{C} 3 \underline{S}$. Kristallografiya 1975, 20, 721-729.

65. Mumme, W.G.; Hill, R.J.; Bushnell-Wye, G.; Segnit, E.R. Rietveld crystal structure refinements, crystal chemistry and calculated powder diffraction data for the polymorphs of dicalcium silicate and related phases. Neues Jahrb. Fuer Mineral. 1995, 169, 35-68.

66. Chaix-Pluchery, O.; Pannetier, J.; Bouillot, J.; Niepce, J.C. Structural prereactional transformations in $\mathrm{Ca}(\mathrm{OH})_{2}$. J. Solid State Chem. 1987, 67, 225-234. [CrossRef]

67. Goetz-Neunhoeffer, F.; Neubauer, J. Refined ettringite $\left(\mathrm{Ca}_{6} \mathrm{Al}_{2}\left(\mathrm{SO}_{4}\right)_{3}(\mathrm{OH})_{12} \cdot 26 \mathrm{HO}\right)$ structure for quantitative X-ray diffraction analysis. Powder Diffr. 2006, 21, 4-11. [CrossRef]

68. Maslen, E.N.; Streltsov, V.A.; Streltsova, N.R.; Ishizawa, N. Electron density and optical anisotropy in rhombohedral carbonates III. Synchrotron X-ray studies of $\mathrm{CaCO}_{3}, \mathrm{MgCO}_{3}$ and $\mathrm{MnCO}_{3}$. Acta Crystallogr. Sect. B 1995, 51, 929-939. [CrossRef]

69. Kamhi, S.R. On the structure of vaterite CaCO3. Acta Crystallogr. 1963, 16, 770-772. [CrossRef]

70. Pokroy, B.; Fieramosca, J.S.; von Dreele, R.B.; Fitch, A.N.; Caspi, E.N.; Zolotoyabko, E. Atomic structure of biogenic aragonite. Chem. Mater. 2007, 19, 3244-3251. [CrossRef]

71. Bezou, C.; Nonat, A.; Mutin, J.-C.; Christensen, A.N.; Lehmann, M.S. Investigation of the Crystal Structure of $\gamma$-CaSO ${ }_{4}, \mathrm{CaSO}_{4}$ $0.5 \mathrm{H}_{2} \mathrm{O}$, and $\mathrm{CaSO}_{4} \cdot 0.6 \mathrm{H}_{2} \mathrm{O}$ by Powder Diffraction Methods. J. Solid State Chem. 1995, 117, 165-176. [CrossRef]

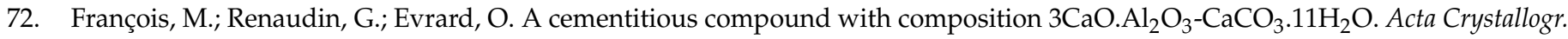
Sect. C Cryst. Struct. Commun. 1998, 54, 1214-1217. [CrossRef]

73. Saalfeld, H.; Wedde, M. Refinement of the crystal structure of gibbsite, $\mathrm{Al}(\mathrm{OH})_{3}$. Z. fur Krist. New Cryst. Struct. 1974, 139, 129-135. [CrossRef] 